\title{
Copper nanoparticles prompt the activity of estuarine denitrifying bacterial communities at relevant environmental concentrations
}

Joana Costa ${ }^{1}$, António G.G. Sousa ${ }^{1}$, Ana Carolina Carneiro ${ }^{1,2}$, Ana Paula Mucha ${ }^{1,2}$, C. Marisa R.

Almeida $^{1,3}$, Catarina Magalhães ${ }^{1,2,4,5}$, Mafalda S. Baptista ${ }^{1,3,6}$ *

*mbaptista@ciimar.up.pt

${ }^{1}$ CIIMAR/CIMAR - Centro Interdisciplinar de Investigação Marinha e Ambiental, Universidade do Porto, Matosinhos, Portugal

${ }^{2}$ Departamento de Biologia, Faculdade de Ciências, Universidade do Porto, Porto, Portugal

${ }^{3}$ Departamento de Química e Bioquímica, Faculdade de Ciências, Universidade do Porto, Porto, Portugal

${ }^{4}$ School of Science, University of Waikato, Hamilton, New Zealand

${ }^{5}$ Ocean Frontier Institute, Dalhousie University, Canada

${ }^{6}$ International Centre for Terrestrial Antarctic Research, University of Waikato, Hamilton, New

Zealand 
bioRxiv preprint doi: https://doi.org/10.1101/2020.07.05.188334; this version posted July 5, 2020. The copyright holder for this preprint (which was not certified by peer review) is the author/funder, who has granted bioRxiv a license to display the preprint in perpetuity. It is made available under aCC-BY-NC-ND 4.0 International license.

Table of contents

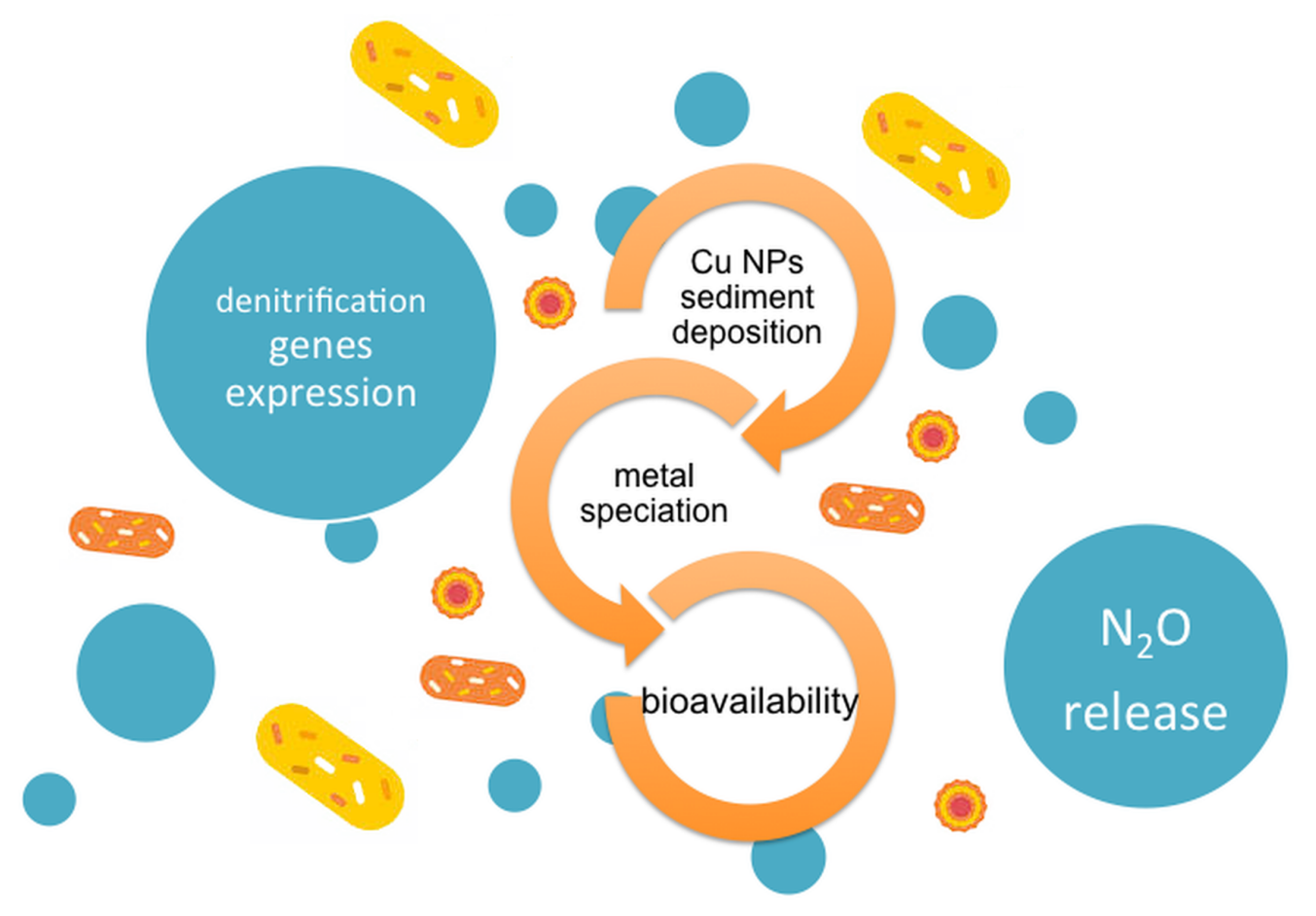

In estuaries the deposition upon the sediments of copper nanoparticles can contribute to change metal availability and promote the activity of denitrifying bacteria 


\section{Abstract}

Effects of metallic nanoparticles (NPs) to the estuarine biota have mostly been shown for concentrations higher than those actually measured or predicted in these environments. To address this gap, a range of concentrations expected to occur in estuarine environments (from 0.01 to $1 \mu \mathrm{g}$ g-1) was employed in microcosms studies to assess the impact of Cu NPs in the denitrification pathway. That was achieved by quantifying gene expression and the potential denitrification rate in estuarine sediments exposed to Cu NPs for up to six days. Expression of nitrite (nirS) and nitrous oxide (nosZ) reductase genes was enhanced in a timewise manner. For the highest Cu NPs $\left(1 \mu \mathrm{g} \mathrm{g}^{-1}\right)$ an increase in gene expression could be seen immediately after $1 \mathrm{~h}$ of exposure, and continuing to be enhanced up until $7 \mathrm{~h}$ of exposure. For the lowest Cu NPs $\left(0.01 \mu \mathrm{g} \mathrm{g}^{-1}\right)$ an increase in gene expression could only be seen after $4 \mathrm{~h}$ or $7 \mathrm{~h}$ of exposure; however it continued to rise up until $24 \mathrm{~h}$ of exposure. In any case, after $48 \mathrm{~h}$ the expression levels were no longer different from the nonexposed control. Concomitantly to increased gene expression the potential denitrification rate was increased by $30 \%$. Our results suggest that deposition and adsorption of Cu NPs to estuarine sediments promotes the immediate and transient expression of key genes of the denitrification pathway. The long term impact of continuous inputs of Cu NPs into estuaries deserves renewed analysis to account for their effects, not just on the biota, but especially on ecosystems services. 


\section{Environmental significance}

Interactions of metallic nanoparticles with microbial communities of estuarine sediments are poorly characterized and its impact towards ecosystem services even less. By assessing the effect of copper nanoparticles on the expression of key genes of the denitrification pathway, an essential step for nitrogen $(\mathrm{N})$ removal, we were able to show that denitrifying communities are immediately activated after exposure, increasing the denitrification rates in estuaries. The importance of denitrification lies in its release of dinitrogen $\left(\mathrm{N}_{2}\right)$ to the atmosphere but also in the emissions of $\mathrm{N}_{2} \mathrm{O}$ (a potent greenhouse gas). The results obtained in this study gather data that contribute information on the denitrification dynamics in estuaries, invaluable for a timely response to the expected upcoming changes in coastal areas. 


\section{Introduction}

The industrial use of nanoparticles (NPs) has had an exponential growth in the past decades. As a consequence, ultimately the aquatic environment becomes the final destination and repository of these NPs and its impact on the health of the ecosystems is a growing concern in environmental science and management. ${ }^{1}$ One of the major classes of engineered nanomaterials are metallic NPs, such as copper (Cu NPs). Due to their versatility, their applications are broad and Cu NPs are currently used for a variety of purposes such as antimicrobials, treatment drugs, food additives, catalysts, surfactants, sensors and semiconductors. ${ }^{2}$ The vast majority of the environmental Cu NPs are nanoparticles derived from agriculture ${ }^{3}$ and antifouling paints. ${ }^{4}$ In agriculture Cu-based nanomaterials are used as pesticides, ${ }^{5}$ or as biosolids from wastewater treatment plants. ${ }^{6}$ Marine antifouling paints can contain up to $50 \% \mathrm{Cu}$ and, therefore, large amounts of $\mathrm{Cu}$ can be released and accumulated in coastal areas. ${ }^{4}$

Once in the aquatic environment NPs can undergo transformations such as aggregation, sedimentation, dissolution, sulfidation, amongst others, and can interact with organic matter. ${ }^{7}$ The type of transformation will depend on the size of the NPs, composition of the NPs surface (charge and functionality) and the environmental conditions. In aquatic environments Cu NPs stability is strongly influenced by salinity and $\mathrm{pH} .{ }^{8}$ Measurements of $\mathrm{Cu}$ NPs dissolution rates have shown this process to be highly variable for freshwater and marine systems. ${ }^{9}$ This variable behaviour poses enhanced difficulties to the assessment of Cu NPs effects, with pronounced differences observed in the responses between species and their physiological variables. ${ }^{10}$ Studies focusing on exposure of aquatic organisms to metallic NPs have shown its consequences to single organisms ${ }^{11}$ but also that, at the community level, species interactions and feedbacks may dampen effects that are seen at the organisms level. ${ }^{12}$ Information related to the environmental risk posed by metallic NPs is still missing largely due to the difficulties involved in the quantification of these particles in the environment. ${ }^{13}$ Because of that, there is great concern in health and environmental issues that may arise from exposure to metallic NPs, even if so far no deleterious effects have been reported, for the range of concentrations expected or predicted to occur in the environment. ${ }^{14}$

In estuaries $\mathrm{Cu}$ can greatly impact ecosystem processes. For example, Cu plays a crucial role in denitrification processes since it is a co-factor to Nirk $\mathrm{NO}_{2}$-reductase and NosZ $\mathrm{N}_{2} \mathrm{O}$-reductase enzymes. ${ }^{15}$ Previous studies have showed the impact of $\mathrm{Cu}$ on the abundance and transcription of genes of the denitrification pathway in an estuarine environment. ${ }^{16,17}$ However, studies specifically addressing the role of $\mathrm{Cu}$ NPs (as opposed to ionic $\mathrm{Cu}$ ), in a range of expected concentrations and of expected sizes are still missing. In this work we address this question by testing the hypothesis that deposition of $\mathrm{Cu}$ NPs in estuarine sediments at environmental relevant concentrations and sizes will 
affect metal bioavailability, which in turn will affect denitrification in estuarine sediment microbial communities.

The Douro estuary, our case study, located on the northwestern Portuguese coast, is under constant anthropogenic pressure due to urban runoffs, sewage discharges, land reclamation and use of pesticides. ${ }^{18}$ The three main cities that border the estuary (ca. 700000 inhabitants) contribute with three major wastewater treatment plants, with effluents being drained to the estuary. Douro River is an international commercial waterway and an increase in traffic, both commercial and touristic, has been registered in recent years. ${ }^{19}$ With this comes an increase in the amount of Cu NPs derived from antifouling paints that can be expected to be released into the river. In past decades Cu-based pesticides were used vastly in the Port wine region and ended up in the Douro watershed, causing concern over the amounts of $\mathrm{Cu}$ in the ecosystem. ${ }^{20}$ Nowadays, $\mathrm{Cu}$ is increasingly being applied as a nanopesticide, ${ }^{5}$ which in spite of the promise of a slower and more controlled release of the active ingredient, still needs to be reapplied to the vineyards to offset the rainfall wash-off just as traditional pesticides did, contributing a point source of Cu NPs in the Douro watershed. 


\section{Experimental}

\subsection{Study site and sample collection}

Douro estuary is located on the north western Portuguese coast (Fig. 1). It is a mesotidal estuary subjected to North Atlantic meteorological and hydrodynamic conditions. ${ }^{21}$ The mouth of the estuary is narrow and two thirds of it is shielded by a sandy spit, creating an ecosystem of great biological interest. For that reason the "Nature Reserve of the Douro Estuary" was step up in 2007 with the aim of protecting the birds and the landscape of this salt marsh.

Sample collection took place at the salt marsh $\left(41^{\circ} 8^{\prime} 28.2588^{\prime \prime} \mathrm{N} 8^{\circ} 39^{\prime} 48.2328^{\prime \prime} \mathrm{W}\right)$, taking care to minimise disturbance to wildlife and habitats. ${ }^{22}$ This site was chosen as it had been characterized in previous studies and showed a sediment grain mostly composed of coarse sand (>0.5 $\mathrm{mm}$ ) and concentration of $\mathrm{Cu}<4.5 \mathrm{\mu g} \mathrm{g}^{-1}$. ${ }^{16}$ The impact of $\mathrm{Cu}$ on denitrification had also been assessed ${ }^{16}$ as well as the impact on diversity, abundance and transcription of genes of the denitrification pathway, ${ }^{17}$ making this site very suitable to compare these data with data derived from Cu NPs exposure.

At low tide, intertidal sandy sediment $(c a .3 \mathrm{~kg})$ were collected with an acrylic core $(10 \mathrm{~cm}$ diameter) at $10 \mathrm{~cm}$ depth and homogenized in sterile Whirl-Paks. Overlying water (ca. $5 \mathrm{~L}$ ) was collected and stored in acid-cleaned Nalgene bottles. Water temperature, dissolved $\mathrm{O}_{2}$, conductivity, salinity and $\mathrm{pH}$, were measured in situ at the time of sampling (Table 1), with a multiparameter probe (pHenomenal ${ }^{\circledR}$ MU $6100 \mathrm{H}, \mathrm{VWR}$ ). Samples were transported to the laboratory refrigerated and in the dark.

\subsection{Nanoparticle dispersions}

Cu NPs were purchased from Sigma-Aldrich as a copper (II) oxide nanopowder, $<50 \mathrm{~nm}$ particle size (TEM) and a copper-zinc alloy nanopowder, < $150 \mathrm{~nm}$ particle size (SEM), 56-60 \% Cu basis, 37-41 \% Zn basis (reference numbers 544868 and 593583, respectively). To produce $100 \mathrm{mg} \mathrm{L}^{-1}$ stock dispersions $10 \mathrm{mg}$ of Cu NPs were added to $1 \mathrm{~mL}$ of deionized water, sonicated for 30 min, vortexed for $30 \mathrm{~s}$, diluted to $10 \mathrm{~mL}$ with filtered estuary water (0.22 $\mu \mathrm{m}$ cellulose membrane, Merck Millipore) containing $10 \mathrm{mg} \mathrm{L}^{-1}$ of chitosan and acetic acid (2\%), and again vortexed for $30 \mathrm{~s}^{12}$ The obtained dispersions were characterized in the Instrumental Laboratory of the Department of Chemistry and Biochemistry, Faculty of Sciences, University of Porto. The hydrodynamic size (DLS) was $33 \pm 12 \mathrm{~nm}$ and $119 \pm 50 \mathrm{~nm}$ for Cu NPs < $50 \mathrm{~nm}$ and < $150 \mathrm{~nm}$, respectively. Cu was analysed by flame atomic absorption spectroscopy (AAS) and the measured amount corresponded to $70 \%$ and $40 \%$ of the initially supplied, for Cu NPs $<50 \mathrm{~nm}$ and $<150 \mathrm{~nm}$, respectively. Working Cu NPs dispersions were prepared daily by diluting the stock with filtered $(0.22 \mu \mathrm{m})$ estuary water. 


\subsection{Microcosms}

Microcosms were established in acid-cleaned glass serum bottles with $60 \mathrm{~g}$ of homogenized sediment and $60 \mathrm{ml}$ of filtered estuary water amended with working Cu NPs dispersions to achieve final concentrations of $0.01,0.1$ or $1 \mu \mathrm{g} \mathrm{g}^{-1}$. Microcosms without Cu NPs addition were prepared in parallel and served as control. For Cu NPs $<50 \mathrm{~nm}$ microcosms were setup with overlaying water of two different salinities, 21 psu (EXP1) and 9 psu (EXP2), respectively, while for Cu NPs $<150 \mathrm{~nm}$ microcosms were setup only with overlaying water of 9 psu salinity. The microcosms were incubated for 6 days with constant agitation (150 rpm), in the dark. At 1, 4, 7, 24, 48 and $144 \mathrm{~h}$ one microcosm per concentration was used to collect water and sediment samples for analysis. At that time water physicochemical parameters were determined as described for the sampling.

Water and homogenized sediment aliquots were kept at $-20 \stackrel{\circ}{ } \mathrm{C}$ for analysis of inorganic $\mathrm{N}$ compounds, $\mathrm{Cu}$ and Fe concentration, organic matter amount and total bacteria enumeration. For analysis of inorganic $\mathrm{N}$ compounds sediments were dried at $105 \stackrel{\circ}{\circ}$ until constant weigh ${ }^{23}$ prior to the analysis. Inorganic ammonium $\left(\mathrm{N}-\mathrm{NH}_{4}{ }^{+}\right)$, nitrite $\left(\mathrm{N}-\mathrm{NO}_{2}{ }^{-}\right)$and nitrate $\left(\mathrm{N}-\mathrm{NO}_{3}{ }^{-}\right)$were spectrophotometrically quantified (UV mini 1240 Shimadzu) on both sediment and overlaying water, in triplicate for each sample, as previously described ${ }^{24}$ and using freshly prepared standards. ${ }^{25}$ The limit of detection was $1,0.1$ and $2 \mu \mathrm{mol} \mathrm{L}{ }^{-1}$ for $\mathrm{N}^{-\mathrm{NH}_{4}}{ }^{+}, \mathrm{N}-\mathrm{NO}_{2}{ }^{-}$, and $\mathrm{N}-\mathrm{NO}_{3}{ }_{3}^{-}$, respectively, and the relative standard deviation (RSD) between replicates varied between 3 and $7 \%$. Consumption or production rates of inorganic $\mathrm{N}$ compounds were calculated from the slopes of the linear regressions of concentration vs time. Fe and $\mathrm{Cu}$ concentrations in the sediment were analysed in the fraction termed "environmentally available" (digested at high pressure with nitric acid) and in the fraction termed "exchangeable" (room-temperature extracted with acetic acid) as previously described. ${ }^{26}$ Samples were analysed in triplicate by AAS, either with flame $(\mathrm{Fe})$ or with electrothermal atomisation $(\mathrm{Cu})$, at the Instrumental Laboratory of the Department of Chemistry and Biochemistry, Faculty of Sciences, University of Porto. Aqueous-matched standards were used for external calibrations. Quality control checks included analysing blanks containing no sediment alongside the samples. The limit of detection was $0.07 \mu \mathrm{g} \mathrm{g}^{-1}$ and $0.005 \mathrm{mg} \mathrm{g}^{-1}$ for $\mathrm{Cu}$ and Fe, respectively, and the RSD between replicates varied between 3 and $5 \%$. Organic matter (OM) content was determined by drying the sediments until constant weight, followed by ignition in a muffle furnace at $500{ }^{\circ} \mathrm{C}$ for $4 \mathrm{~h}$ and then reweighing. For total bacteria enumeration homogenized sediment ( $c a .0 .5 \mathrm{~g}$ ) was treated with a saline solution $\left(9 \mathrm{~g} \mathrm{~L}^{-1} \mathrm{NaCl}\right)$ containing $12.5 \%(\mathrm{v} / \mathrm{v})$ of Tween 80 and fixed with $4 \%(\mathrm{v} / \mathrm{v})$ of formaldehyde. The slurries were stirred at $150 \mathrm{rpm}$ for $15 \mathrm{~min}$, followed by sonication for $20-30 \mathrm{~s}$, at a low intensity. Subsamples of the slurries were then stained with $0.5 \mathrm{mg} \mathrm{mL}^{-1}$ of DAPI (4',6diamidino-2-phenylindole) and incubated in the dark for $12 \mathrm{~min}$. Samples were filtered onto black 
polycarbonate filters ( $0.2 \mu \mathrm{m}$ Whatman Nuclepore) and washed with distilled water under gentle vacuum. All used solutions were $0.2 \mu \mathrm{m}$-filtered and when appropriate autoclaved. Membranes were set up in glass slides and cells were counted on an epifluorescence microscope (Olympus BX41 coupled to a U-CMAD3 camera adapter). A minimum of fifteen pictures were taken running through the entire slide (inverted S) and subsequent cell enumeration was performed with ImageJ. ${ }^{27}$

Sediment aliquots for nucleic acids extraction were kept in LifeGuard Soil Preservation Solution (Qiagen) at $-80^{\circ} \mathrm{C}$. Total RNA and DNA were extracted from approximately $2 \mathrm{~g}$ of sediments with RNeasy PowerSoil Total RNA Kit and RNeasy PowerSoil DNA Elution Kit (Qiagen), respectively. RNA was reverse transcribed using the Maxima First Strand cDNA Synthesis Kit (Thermo Scientific). Kits were used according to the manufacturer's instructions. Quantification of nucleic acids was performed with Qubit 3.0 using either ssDNA or dsDNA HS Assay Kit (Invitrogen), as appropriate.

\subsection{Quantification of gene expression and abundance}

An in silico analysis was carried out based on data from a diversity assessment (16S rRNA gene) previously performed at the Douro estuary, ${ }^{28}$ in order to choose the primers with the widest possible coverage (Supplementary Information, Table S1). Based on the results we selected the primers that target sequences affiliated with nirK in Cluster II (nirKC2F/nirKC2R) and nirS in Cluster I (nirSC1F/nirSC1R), ${ }^{29}$ and nosZ in Clade I (nosZ2F/nosZ2R), ${ }^{30}$ as being the most representative in our dataset. The $16 \mathrm{~S}$ rRNA gene was amplified with the bacterial primers $341 \mathrm{~F} / 534 \mathrm{R}$ and was used as reference gene. ${ }^{31}$

To determine gene expression nirS and nosZ were amplified from the cDNA samples by reverse transcription quantitative real-time PCR (RT-qPCR), and nirk was amplified from the DNA samples by qPCR, both performed in a StepOnePlus real-time PCR System (Applied Biosystems) using Power SYBR Green PCR Master Mix (ThermoFisher Scientific). A serial dilution of a template pooled from six to eight microcosms samples was always included in order to estimate the amplification efficiency of each gene with each sample. ${ }^{32}$ The slope and correlation coefficients of the standard curves and the PCR efficiency $(E)$ were calculated with the built-in software of the equipment (software v2.3). Relative quantification of gene expression was performed by the $2^{-\Delta \Delta C T}$ method, ${ }^{33}$ assessing the change in the expression of nirk, nirS and nosZ relative to the control without Cu NPs addition, and using 165 rRNA as reference, after ascertaining that its expression did not change over time. Differentially expressed genes were identified by taking into account the number of standard deviations by which a value was above or below the mean log2 fold change. ${ }^{34}$ This allowed defining a global fold-change difference and confidence and genes were considered differentially expressed when the $\log 2$ fold change had an absolute value higher than four. Absolute quantification to determine gene expression in numbers of copies was performed with a standard curve obtained 
from DNA extracted from bacteria Roseobacter denitrificans (DSMZ-German Collection of Microorganisms and Cell Cultures $\mathrm{GmbH}$ ), after ascertaining it had the functional genes nirS and nosZ, and cloned using the TOPO-TA cloning kit with PCR 2.1-TOPO and One Shot TOP10 Chemically Competent E. coli (Invitrogen - Thermo Fisher), as described in the Supplementary Information. Results are reported in copy number per gram dry sediment, where the weight of the sediment used in DNA extraction was corrected for the water content. The change in abundance of nirS and nosZ was defined as the ratio of the $\log 10$ of gene copies to 165 rRNA copies. Samples were run in duplicate, controls without template were always run in parallel with the samples, and the melting curves were always analysed to confirm that only target genes were quantified. ${ }^{35}$ Information regarding reaction mixtures and thermal programs is summarized in the Supplementary Information, Table S2, following the MIQE guidelines. ${ }^{36}$

\subsection{Measurement of N2O production rates and determination of potential denitrification activity}

$\mathrm{N}_{2} \mathrm{O}$ production rates were measured using the acetylene $\left(\mathrm{C}_{2} \mathrm{H}_{2}\right)$ inhibition technique. Homogenized sediment $(5 \mathrm{~g}$ ) were weighted into $50-\mathrm{mL}$ serum bottles and covered with $10 \mathrm{~mL}$ of $0.22 \mu \mathrm{m}$-filtered estuarine water, amended with $\mathrm{KNO}_{3}$ (to a final concentration of $50 \mu \mathrm{mol} \mathrm{L}^{-1}$ ) and with the respective Cu NPs dispersion to achieve final concentrations of $0.01,0.1$ or $1 \mu \mathrm{g} \mathrm{g}^{-1}$. Controls consisted of sediments without Cu NPs addition. Serum bottles were purged with $\mathrm{N}_{2}$ for 15 min and $\mathrm{C}_{2} \mathrm{H}_{2}$ was injected (15\% of the headspace) into the bottles. Each treatment was incubated with and without $\mathrm{C}_{2} \mathrm{H}_{2}$, for $4 \mathrm{~h}$ and $7 \mathrm{~h}$, in duplicate, in the dark, at $150 \mathrm{rpm}$. The linearity of the process within this time frame had been confirmed before. ${ }^{24}$

Gas samples were collected from the serum bottles, after headspace equilibration via vigorous shaking, and immediately injected into a Varian gas chromatograph (CP-3800) equipped with an electron captor detector (ECD) held at $250^{\circ} \mathrm{C}$. Separation was achieved on two HayeSep D columns (0.9 and $1.8 \mathrm{~m}$ ), kept at $80{ }^{\circ} \mathrm{C}$, using a mixture of $5 \%$ methane in argon as a carrier gas.

Concentration was calculated using a certified standard with a concentration of $100 \mathrm{ppm}\left(\mathrm{N}_{2} \mathrm{O}\right.$ in He). To account for $\mathrm{N}_{2} \mathrm{O}$ dissolved in solution Bunsen coefficients $\left(\mathrm{T}=25^{\circ} \mathrm{C}, \mathrm{P}=1 \mathrm{~atm}\right)$ were used to calculate the amount of gas dissolved in the liquid phase from the concentration in the gas phase. ${ }^{37}$ The amount of $\mathrm{N}_{2} \mathrm{O}$ produced was calculated by dividing by the wet weight of the sediment and $\mathrm{N}_{2} \mathrm{O}$ production rates were calculated from the slopes of the linear regressions of concentration $v s$ time. Potential denitrification rates were calculated from the $\mathrm{N}_{2} \mathrm{O}$ produced with and without $\mathrm{C}_{2} \mathrm{H}_{2}$. Inorganic $\mathrm{N}$ compounds concentrations were determined for each sample, as described in 2.3 , and used to calculate consumption or production rates from the slopes of the linear regressions of concentration vs time. 


\subsection{Data analysis}

$R$ v.3.5.1 was used for the analysis ${ }^{38}$ with Base $R$ and package 'tidyverse' v.1.2.1. ${ }^{39}$ Plots were produced using R packages 'ggplot2' v.3.2.0, ${ }^{40}$ 'cowplot' v.1.0.0 ${ }^{41}$ and 'scales' v.1.1.0 ${ }^{42}$. Maps were obtained on Google Maps (https://maps.google.com) and Natural Earth (https://www.naturalearthdata.com) and created with QGIS v.3.6 ${ }^{43}$ and R packages 'ggplot2', 'sf' v.0.8.1, ${ }^{44}$ and 'ggspatial' v.1.0.3. ${ }^{45}$ Kruskal-Wallis tests were performed to compare the response of a variable across the different microcosms, after ascertaining that the data did not follow a normal distribution (Shapiro-Wilk test); whenever a difference was found a Wilcoxon rank-sum test, using a Benjamini-Hochberg correction for multiple testing, was conducted to test for pairwise differences between microcosms. Pearson's correlation coefficient was employed to assess linear responses of microcosms parameters over time and the slopes of those responses were compared with a $t$-test. Estimation plots were computed and generated with R package 'dabestr' v.0.2.3. ${ }^{46}$ To assess dissimilarities between different microcosms data were standardized, euclidean distances were calculated with function vegdist in R package 'vegan' v.2.5.5 ${ }^{47}$ and represented in a principal coordinate analyses (PCOA). ${ }^{48}$ Differences between groups were assessed with a PERMANOVA ${ }^{49}$ based on 999 permutations and performed with the function adonis2, after testing for the homogeneity of group dispersions with the function permutest.betadisper, both in R package 'vegan'. Data and code for the analysis and figures are available at https://github.com/msbaptista/Copper_nanoparticle_estuary 


\section{Results}

\subsection{Microcosms conditions over the time of exposure}

In this work the estuary water never displayed salt wedge characteristics, i.e. salinity equal to or higher than 30 psu (Table 1). Douro estuary has been described as a salt wedge. However, for the lower estuary section where the sampling took place, the oceanic water intrusion has been shown to be absent from early December until late March. ${ }^{21}$ Accordingly, in these circumstances it was considered that when assessing the response of specific genes of the denitrification pathway, salinity would not be a factor of variability. To back this assumption microcosms exposed to Cu NPs $<50 \mathrm{~nm}$ set up with overlaying water of either 21 or 9 psu salinity were compared. The influence of salinity in the denitrification process has been considered as one of the most important environmental constraints of this $\mathrm{N}$ cycle pathway in estuaries. ${ }^{50}$ Salinity is also known to potentiate the mobility of $\mathrm{Cu}$ in soils and sediments, ${ }^{51,52}$ and to greatly influence the behaviour of Cu NPs. ${ }^{8}$

A PCoA showed that $\mathrm{Cu}$ concentration over time displayed the same behaviour for both salinities (Fig. 1S), and a PERMANOVA showed that differences in Cu concentration for both salinities were not significant $(F=0.420)$ whereas for time points a slightly significant difference could be seen $(F=1.571)$. Testing the data dispersion showed it was not homogeneous $(F=3.244)$, and thus the significant result for time points was interpreted as reflecting the dispersion of the data instead. To further investigate the effect of time, linear regressions of the physicochemical parameters in the microcosms were analysed. Only $\mathrm{pH}$ and $\mathrm{N}-\mathrm{NO}_{3}{ }^{-}$concentration in water increased in a time dependent manner ( $p$-value $<0.001)$. A $t$-test showed no differences in the increases in the two salinity regimes ( $p$-value $=0.732$ and 0.179 , for $\mathrm{pH}$ and $\mathrm{N}-\mathrm{NO}_{3}{ }^{-}$, respectively), showing the temporal dynamics to be similar regardless of the salinity value.

After ascertaining that salinity was neither influencing the microcosms response during the time-course experiment, neither the $\mathrm{Cu}$ concentration, the size and amount of $\mathrm{Cu}$ NPs, and number of bacterial cells in the sediment were the variables considered to assess the response of the microcosms throughout the exposure period. A PCoA showed that, for both $\mathrm{Cu}$ NPs $<50 \mathrm{~nm}$ and $<$ $150 \mathrm{~nm}$, samples within the first $24 \mathrm{~h}$ were grouped closer than after 48 or $144 \mathrm{~h}$ (Fig. 2A). In accordance, a PERMANOVA showed that differences in Cu concentration were not significant $(F=$ 1.086) whereas differences in time and size were $(F=4.386$ and 16.71 , respectively). Since the dispersions of these groups were not significant ( $F=0.828$ and 0.595 for time and size, respectively) the results of the PERMANOVA were interpreted as reflecting differences in the microcosms exposed to different sizes of $\mathrm{Cu}$ NPs over time. Once again, regarding the physicochemical parameters, $\mathrm{pH}$ and $\mathrm{N}-\mathrm{NO}_{3}{ }^{-}$concentration in water increase over time (Table S3). Comparing these increases in microcosms exposed to $\mathrm{Cu} N \mathrm{NS}<50 \mathrm{~nm}$ and $<150 \mathrm{~nm}$ with a $t$-test showed that only $\mathrm{N}-\mathrm{NO}_{3}{ }^{-}$ 
concentration in water had a different behaviour for both sizes ( $p$-value $=7.40 \mathrm{E}-05)$, with a slightly higher increase in the microcosms exposed to Cu NPs $<50 \mathrm{~nm}$.

Potential toxicity for prokaryotes resulting from the addition of $\mathrm{Cu}$ NPs to the sediment was not expected, given the range of concentrations tested and what is currently known regarding toxicity effects of Cu NPs towards the aquatic biota. ${ }^{2}$ In line with this assumption no toxicity of $\mathrm{Cu}$ NPs, evaluated by a decrease in number of bacteria, could be seen. Quite the opposite, bacterial cell numbers were slightly higher (Kruskal-Wallis test, $p$-value $=0.008$ ) in microcosms exposed to Cu NPs $<50 \mathrm{~nm}$ than in microcosms not exposed to Cu NPs, with the estimation plots showing higher average cell number for microcosms exposed to 0.01 and $1 \mu \mathrm{g} \mathrm{g}^{-1} \mathrm{Cu}$ NPs $<50 \mathrm{~nm}$ (Fig. 2B).

$\mathrm{Cu}$ concentration in the sediments used to establish the microcosms was $4.5 \pm 0.7 \mu \mathrm{g} \mathrm{g}^{-1}(\mathrm{n}=$ 6), similar to previous reports at the same sampling location, ${ }^{16}$ which shows that $\mathrm{Cu}$ concentration has remained fairly constant throughout the years. Taking into account that environmental levels of Cu were ca. 4 times higher than the highest ones tested in this work, and considering their variation $( \pm 0.7)$, we did not expect to be able to detected differences in microcosms upon Cu NPs addition and measurement by AAS. In fact, Cu environmentally available fraction showed no differences between microcosms (Fig. 2C). Cu exchangeable fraction, however, seemed to increase slightly in microcosms exposed to $1 \mu \mathrm{g} \mathrm{g}^{-1} \mathrm{Cu}$ NPs $<50 \mathrm{~nm}$ (Fig. 2D), the estimation plot showing the average value in these microcosms to be higher than the average value in microcosms not exposed to $\mathrm{Cu}$ NPs, hinting at a higher $\mathrm{Cu}$ bioavailability. However, for the $\mathrm{Cu}$ exchangeable fraction it is also possible to see a higher variability in the microcosms not exposed to Cu NPs. Cu exchangeable fractions previously reported for the sediments of Douro estuary and Douro tributaries showed great variation according, for instance, to the occurrence of algae blooms ${ }^{26}$ or plant colonization of the sediment. ${ }^{53}$ Since this extraction procedure assesses the metal fraction more weakly bound to the sediment it is more prone to variation, as weakly bound metals are released more stochastically. Fe environmentally available and exchangeable fractions in sediments did not show differences between microcosms. Cu environmentally available fractions in sediments are often normalised to the Fe fractions, since this element, particularly when employing total-recoverable digestions as we do in this work, can be appropriately used as a conservative tracer, and, moreover, this ratio can be a more useful tool in predicting disturbances in sediment biota communities than elemental concentrations alone. ${ }^{20}$ Normalised Cu concentrations did not vary in this work (Fig. 2S) reflecting the even impact $\mathrm{Cu}$ NPs addition to the microcosms.

Taken together these data indicate that the microcosms exposed for up to 6 days maintained similar physicochemical conditions in water and sediment exposed over time. A clear distinction between microcosms exposed to different $\mathrm{Cu}$ NPs sizes could be seen. For microcosms exposed to 
$\mathrm{Cu}$ NPs $<50 \mathrm{~nm}$ the number of bacterial cells and the Cu exchangeable fraction in the sediment increased in a concentration dependent manner, which for microcosms exposed to Cu NPs $<150 \mathrm{~nm}$ could not be seen.

\subsection{Gene expression response to Cu NPs of different sizes}

Further strengthening the differences between microcosms exposed to different Cu NPs sizes, a distinct pattern of gene expression could be seen. For microcosms exposed to Cu NPs $<50 \mathrm{~nm}$ the expression of nirS and nosZ increased in the first $24 \mathrm{~h}$, whereas for microcosms exposed to Cu NPs $<$ $150 \mathrm{~nm}$ no substantial change in gene expression could be seen (Fig. 3).

For microcosms exposed to $0.01 \mathrm{\mu g} \mathrm{g}^{-1} \mathrm{Cu}$ NPs $<50 \mathrm{~nm}$ substantial increases in gene transcripts could be seen after $4 \mathrm{~h}$ (nosZ) or $7 \mathrm{~h}$ (nirS) and continuing to increase up to $24 \mathrm{~h}$, when the highest expression was obtained. For $0.1 \mu \mathrm{g} \mathrm{g}^{-1}$ a peak in expression could be seen after $7 \mathrm{~h}$ of exposure, and for $1 \mu \mathrm{g} \mathrm{g}^{-1}$ increases in expression could be seen immediately after $1 \mathrm{~h}$ of exposure and continuing to increase up to $4 \mathrm{~h}$, time after which the expression decreased (Fig. 3A-C). nirK expression in microcosms exposed to Cu NPs $<50 \mathrm{~nm}$ followed roughly the same pattern seen for nirS and nosZ, but the smaller log2 fold change in gene transcripts was interpreted as not representing significant differences compared to the control (Fig. 3E). The same smaller log2 fold change in gene expression could be seen for all the microcosms exposed to Cu NPs $<150 \mathrm{~nm}$, which again was interpreted as not representing significant differences to the control (Fig. 3B-D). Given that the gene expression analysis was performed in a sequential manner, starting with microcosms exposed to Cu NPs $<50 \mathrm{~nm}$, it was considered not worth it to analyse nirK transcripts in microcosms exposed to Cu NPs $<150 \mathrm{~nm}$, as overall analysis of the data suggested that those would not be different from the control. After $48 \mathrm{~h}$ of exposure no changes could be seen in gene expression for any microcosm exposed to Cu NPs, a situation that was still maintained by the end of the of exposure, after 6 days, corroborating the results seen with the PCoA analysis (Fig. 2A) that samples obtained in the first $24 \mathrm{~h}$ were separated from the subsequent ones.

Gene expression showed a strong dependence of time and Cu NPs $<50 \mathrm{~nm}$ amount. The earliest increases in gene expression occurred for the highest Cu NPs additions, for which a peak was achieved after $4 \mathrm{~h}$ of exposure. Conversely, the lowest Cu NPs additions only showed increases in gene expression after $4 \mathrm{~h}$ or $7 \mathrm{~h}$ of exposure, but that continued to increase until $24 \mathrm{~h}$ achieving an overall higher gene expression. To check if the addition of $\mathrm{Cu}$ was reflected at the gene level, we investigated nirS and nosZ copy numbers for the microcosms exposed to Cu NPs $<50 \mathrm{~nm}$. As can be seen in Fig. 4(A-B), the increase in gene copy numbers followed the same temporal and concentration trends described for the gene transcripts, with $0.01 \mu \mathrm{g} \mathrm{g}^{-1}$ showing a peak after $24 \mathrm{~h}$, $0.1 \mu \mathrm{g} \mathrm{g}^{-1}$ showing a peak after $7 \mathrm{~h}$ and $1 \mu \mathrm{g} \mathrm{g}^{-1}$ showing a peak after $4 \mathrm{~h}$ of exposure, and with the 
highest gene copy number obtained for $0.01 \mu \mathrm{g} \mathrm{g}{ }^{-1}$ after $24 \mathrm{~h}$. When normalizing nirS and nos $\mathrm{Z}$ by 16S rRNA copy number, to account for fluctuations in the number of cells, it was possible to see an increase in the number of nirS and nosZ genes in microcosms exposed to increasing concentrations of Cu NPs $<50 \mathrm{~nm}$ (Fig. 4C-D). However, a higher variability of copy numbers could also be seen for the microcosms exposed, highlighting the diffused contribution of $\mathrm{Cu}$ NPs to the observed changes.

Studies comparing the abundance of nir and nos $Z$ in various environments (eg. soils, sediments) have shown that the number of nir genes can exceed that of nosZ by orders of magnitude, ${ }^{54}$ as well as that nirS can be consistently more abundant than nirK in estuaries. ${ }^{55}$ These same findings could be seen for this work, showing these to be the conditions of Douro estuary and showing that these were captured on the microcosms setup. On microcosms not exposed to Cu NPs nirS abundance showed a correlation to bacterial 16S $r R N A$ abundance (Pearson's $r=0.511, p$-value $=0.110$ ), whereas nos $Z$ did not (Pearson's $r=0.012, p$-value $=0.836$ ); moreover nirS and nos $Z$ were also not correlated with each other (Pearson's $r=0.221, p$-value $=0.347$ ). Conversely, for the microcosms exposed to Cu NPs, nirS and nosZ abundances were positively correlated for all three concentrations tested (Fig. 3S), suggesting a similar response from the denitrifier community. Known sequenced genomes show that most microorganisms carry one copy of either nirk or nirs. ${ }^{56}$ However, from the genomes that possess nir genes approximately two thirds is currently known to harbour nos $Z$ as well. ${ }^{57}$ Therefore, the correlations obtained with this work hint at the possible presence of both genes in the better part of the denitrifier community of Douro estuary.

\subsection{Potential denitrification in sediments exposed to Cu NPs}

The potential denitrification rate ( $\mathrm{N}_{2}$ plus $\mathrm{N}_{2} \mathrm{O}$ production) was determined for the microcosms for which a change in gene expression had been seen, namely those exposed to Cu NPs $<50 \mathrm{~nm}$. The results showed an overall average of $30 \%$ higher in sediments exposed to Cu NPs (Fig. 5A), increasing by $22 \%, 24 \%$ and $42 \%$, for $0.01,0.1$ and $1 \mu \mathrm{g} \mathrm{g}^{-1}$, when compared to the non-exposed control. The consumption of $\mathrm{N}^{-\mathrm{NO}_{2}}{ }^{-}$was highest for sediments exposed to $1 \mu \mathrm{g} \mathrm{g}^{-1}$ (Fig. 5B), which showed the highest potential denitrification rate as well. For the remaining concentrations, higher productions of $\mathrm{N}_{2}$ plus $\mathrm{N}_{2} \mathrm{O}$ were associated with slightly higher consumptions of $\mathrm{N}^{-\mathrm{NO}_{2}}{ }^{-}$for $0.01 \mu \mathrm{g}$ $\mathrm{g}^{-1}$, however, for $0.1 \mu \mathrm{g} \mathrm{g}^{-1}$ the same trend could not be seen.

Gene expression up until $7 \mathrm{~h}$ was swifter under $1 \mu \mathrm{g} \mathrm{g}^{-1}$ exposure (Fig. 3A \& C), and these results are reflected in the potential denitrification and $\mathrm{N}^{-\mathrm{NO}_{2}}$ consumption rates that were seen. Though the highest gene expression seen in this study was for $0.01 \mu \mathrm{g} \mathrm{g}^{-1}$ after $24 \mathrm{~h}$, incubations to determine potential denitrification rates did not continue up to this hour due to the fact that these would fall outside the linearity of the employed method. ${ }^{24}$ Linear accumulation of $\mathrm{N}_{2} \mathrm{O}$ is used as evidence for the validity of the results, as the acetylene inhibition technique is known to have time 
dependent bias that contribute to underestimating the denitrification rates. ${ }^{37}$ Specifically the

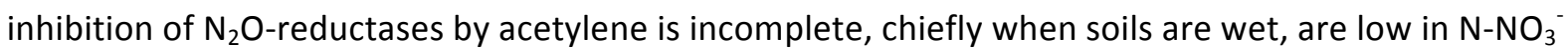
or have a high $\mathrm{C}: \mathrm{N}^{-\mathrm{NO}_{3}}{ }_{3}^{-}$ratio. Also, acetylene has been reported to inhibit key enzymes involved in nitrification (ammonium monooxygenase), thus affecting denitrification rates when the amount of $\mathrm{N}-\mathrm{NO}_{2}{ }^{-}$or $\mathrm{N}-\mathrm{NO}_{3}{ }^{-}$available for this pathway is compromised. ${ }^{58}$ To overcome these issues additions $\mathrm{N}-\mathrm{NO}_{3}{ }^{-}$to are often performed when estimating the denitrifying potential of the sediments ${ }^{37}$ and, in this work, doing that resulted in the pool of $\mathrm{N}^{-\mathrm{NO}_{3}}{ }^{-}$remaining unchanged up to $7 \mathrm{~h}$.

Other studies ${ }^{59}$ at Douro estuary have shown that the variability in $\mathrm{N}-\mathrm{NO}_{3}{ }_{3}^{-}$concentrations modulates the magnitude of the denitrifying process, with potential denitrification rates ranging from 0.4 to $38 \mathrm{nmol} \mathrm{N} \mathrm{g}^{-1} \mathrm{~h}^{-1}$ and varying greatly according to the different substrates studied, time of the day, or season. ${ }^{24}$ Rates measured with the isotope pairing technique, a more powerful tool to investigate rates of microbial mediated nitrogen processes ${ }^{60}$ has shown denitrification at Douro estuary to vary between $4-8 \mathrm{nmol} \mathrm{N} \mathrm{g}^{-1} \mathrm{~h}^{-1},{ }^{61}$ encompassing the ranges obtained in this study, and contributing to corroborate that, in spite of its simplicity, the acetylene inhibition method is a useful tool for relative comparisons of denitrification rates. 


\section{Discussion}

In this work we addressed two noteworthy issues regarding the effect of Cu NPs upon estuarine microbial communities that have often been overlooked, by looking into the effects of environmentally-relevant concentrations and by assessing the impact of Cu NPs not only on the microbial communities but on the ecosystem services they provide, namely the service of removing fixed nitrogen, which is critical in eutrophic ecosystems.

Previous works have shown that the size of metallic NPs could better predict its toxicity than the metal content ${ }^{62}$ and in accordance our data shows that microbial communities in the estuarine sediment responded to additions of $\mathrm{Cu}$ NPs $<50 \mathrm{~nm}$, but not to additions of Cu NPs $<150 \mathrm{~nm}$. The characterization of the NPs in the stock dispersion showed sizes of ca. 30 and $120 \mathrm{~nm}$, for Cu NPs < $50 \mathrm{~nm}$ and $<150 \mathrm{~nm}$, respectively. Therefore, Cu NPs < $150 \mathrm{~nm}$ were still larger than $100 \mathrm{~nm}$, a size that has often been described as the upper limit for a material to be considered a NP and, thus, to behave as such. ${ }^{63}$ The Cu NPs $<150 \mathrm{~nm}$ used in this work were an alloy with ca. $60 \% \mathrm{Cu}$, which was reflected in the amount of Cu measured in the NPs dispersions (40\% of the nominal concentration vs $70 \%$ for Cu NPs < $50 \mathrm{~nm}$ ). Despite this, the estimated actual tested concentrations for both NPs sizes were of the same magnitude, and ranged from $7 \times 10^{-3}-10^{-1} \mathrm{\mu g} \mathrm{g}^{-1}$ to $4 \times 10^{-3}-10^{-1} \mathrm{\mu g} \mathrm{g}^{-1}$, for Cu NPs $<50 \mathrm{~nm}$ and $<150 \mathrm{~nm}$, respectively. Cu NPs have been predicted to occur in the environment, specifically in freshwater and seawater systems, in ranges of $\mu \mathrm{g} p e r \mathrm{~kg}$, with the lowest Cu amount tested in this work corresponding to the upper predicted limits. ${ }^{2,64}$ At these values no toxicity towards the estuarine sediment bacterial community could be seen. Notwithstanding the other tested concentrations being above the upper limit of predicted environmental concentrations, they also did not show a toxicity effect. Other studies have shown no toxic effects on bacteria exposed up to $10 \mathrm{mg} \mathrm{L}^{-1} \mathrm{Cu}$ NPs, both on freshwater and seawater, ${ }^{9,65}$ indicating a high tolerance to $\mathrm{Cu}$ in the NP form. The nature of the antimicrobial activity of metal-containing NPs is still under debate, particularly whether toxicity is mostly caused by the release of metal ions, by the disruption of the outer cell membranes integrity, or by the NP penetrating biological systems and contributing to cytotoxicity and genotoxicity, and the formation of reactive oxygen species. In a microcosms exposed to $50 \mathrm{~nm} \mathrm{Cu} \mathrm{NPs} \mathrm{(} \mathrm{pH}=7.8$, comparable to this work's $\mathrm{pH}=8$ ) the dissolved $\mathrm{Cu}$ was shown to increase in a time dependent manner, with highest dissolution rates in the first $24 \mathrm{~h}$, but consistently more than $50 \%$ of the Cu remained undissolved and as a NP, for up to five days of exposure. ${ }^{65}$ These data suggest that in this work the Cu NPs remained predominantly as a NP in the microcosms and that the effects seen on gene expression were caused by their intrinsic properties rather than by the release of metal ions and corresponding dissolution.

The better part of the studies pertaining the impact of Cu NPs (and other metallic NPs) on 
biota have focused on establishing effect concentrations in order to predict exposure reference doses that could inform risk assessment frameworks and regulations. ${ }^{7}$ Instead, in this work we enquired what possible implications the existing amounts of Cu NPs in the ecosystem could have towards the biota. Implications for the estuarine microbial communities were considered based on the fact that genes of the denitrification pathway can be regulated in response to the extracellular $\mathrm{Cu} .{ }^{15}$ Copper is a necessary co-factor in key enzymes of the denitrification process, namely the nitrous oxide reductase (NosZ) and the nitrite reductase (NirK). NosZ shows very similar properties when purified from a wide range of bacteria of diverse metabolic groups. ${ }^{66}$ For Nirk, however, three different classes have been suggested based on differences on structure, but several known Nirk have structures that do not fit any of the current classes. ${ }^{55}$ The co-occurrence of nos $Z$ with nirs in the aquatic environment is more frequent than the co-occurrence with nirk, ${ }^{67}$ and an analysis of the Douro estuary microbial community showed that for Douro estuary this was the case (Supplementary Information, Table S1). Moroever, the concomitant increase in gene expression and copy number of both nirS and nosZ suggested that the community was composed by microorganisms that harboured both genes. Therefore, considering nirS and nosZ co-occurrence within the same microorganism, the impact of Cu NPs could have meant more available Cu to drive the expression of nosZ, which in turn would lead to the expression of nirS, since its expression would be necessary for the production of the substrate on which the nitrous oxide reductase would act upon. The analysis of the Douro estuary microbial community also showed that nirs could potentially be present in genera accounting for $1.3 \%$ of the overall relative abundance whereas nirk genera could potentially account for $0.2 \%$ of the overall relative abundance, enabling the assumption that the microcosms community was mostly comprised of nirS-containing organisms. The corresponding impact of Cu NPs on the change of nirK expression might not have been captured for the microcosms community due to the reduced number of microorganisms within the denitrifying community that harboured this gene. It could also have happen that under the chosen exposure conditions the expression of nirk was not enhanced due to lack of impact from the Cu NPs.

In this work we have showed that ecosystem services could be impacted by Cu NPs by ascertaining that both an increase in the expression of genes of the denitrification pathway and in $\mathrm{N}_{2} \mathrm{O}$ production were seen, after exposure to NPs. This relationship, instrumental to improve the prediction of rates of denitrification, cannot always be shown. Other works have reported that an increase in the denitrifying activity is not always associated with an increase in transcript or gene abundance. ${ }^{68-70}$ One of the reasons for this might be the modular character of the denitrification pathway, in that an organism does not always possesses the set of enzymes necessary to carry out the entire process. At Douro estuary $\mathrm{Cu}$ amendments of $4 \mu \mathrm{g} \mathrm{g}^{-1}$ (equal to the environmental 
measured levels) led to a reduction of total $\mathrm{N}$ removal via denitrification, at the same time that the release of $\mathrm{N}_{2} \mathrm{O}$ was enhanced. Furthermore, this amendment yielded a decrease in the abundance of nirk, nirS and nosZ transcripts. ${ }^{16,17}$ Cultures of the representative denitrifying bacteria Pseudomonas stutzeri have shown that decreasing the $\mathrm{Cu}$ concentration resulted in the accumulation of $\mathrm{N}_{2} \mathrm{O}$, compared to Cu-replete cultures. ${ }^{71}$ However, the highest concentrations of $\mathrm{N}_{2} \mathrm{O}$ were not produced in $\mathrm{Cu}$-deficient cultures but at $\mathrm{Cu}$ levels for which the lowest proportion of $\mathrm{N}_{2} \mathrm{O}$ to $\mathrm{N}_{2}$ levels were generated. ${ }^{72}$ Increasing the $\mathrm{Cu}$ concentration also increased the expression of nirS and nosZ, up until a concentration for which the transcription was inhibited, suggesting a differentiated production of $\mathrm{N}_{2} \mathrm{O}$ by $P$. stutzeri at lower or higher levels of $\mathrm{Cu} .{ }^{72}$ The results obtained in this work show Cu NPs at the tested concentrations increasing the expression of genes of the denitrification pathway and contributing to the overall removal of $\mathrm{N}$ from the Douro estuary as $\mathrm{N}_{2}$, since the tested concentrations of Cu NPs are not toxic and, therefore, do not inhibit nosZ expression.

The ecological implications of these findings concern the fact that $\mathrm{N}_{2} \mathrm{O}$ is a potent greenhouse gas, and also the one who contributes the most to the destruction of the ozone layer, ${ }^{73}$ and the fact that in estuarine environments $\mathrm{Cu}$ concentration gradients can often be found. The Douro estuary, similarly to many others, harbours sediments displaying concentrations of $\mathrm{Cu}$ that are much higher than any up-to-date or predicted input of Cu NPs. However, as this work showed, inputs of metallic NPs into the environment should not be disregarded based on the fact that they constitute only a small fraction of the total metal content of the ecosystem. A comprehensive review of NPs in soils found reports that these could lead to reduced diversity and function of soil microorganisms, or could have no measurable effect, or could have positive effects on soil microbial communities and functioning, leading to the conclusion that, above all, NP-microbe interactions are context-driven. ${ }^{74}$ The best way to address these inconsistencies is by ensuring that experiments are conducted under more realistic environmental conditions, which was attempted with this work. Limitations of this work include the fact that it did not enquire about Cu NPs internalization, or cell wall binding, in prokaryotic cells. In the future, this understanding of the interactions between microorganisms and $\mathrm{Cu}$ NPs, will enable disentangling the effects of $\mathrm{Cu}$ as NP or as ion, and will be invaluable to establish causality between exposure to $\mathrm{Cu}$ NPs and increased gene expression and $\mathrm{N}_{2} \mathrm{O}$ emissions. 


\section{Conclusion}

Nanotechnology, operating at a scale much smaller than any other, has shown how much it can impact living beings in vitro; but in vivo studies are only just starting to grasp the many implications that nNPs can pose towards organisms. The macroscale at which we measure the better part of the processes we aim at studying might be inadequate to assess the microscale at which the prokaryotic communities thrive and change, and the nanoscale at which NPsoperate. In this work we have began to find a way of interconnecting these findings by showing that CU NPs, at concentrations that when assessed by classic toxicity studies do not exhibit either toxic or hormetic effects, can actually have an effect on biological pathways and impact important steps of the $\mathrm{N}$ cycle. Future studies on the long term impact of continuous inputs of metallic NPs on estuarine environments will enable the understanding of the possible multiple outcomes for microbial ecosystem services.

\section{Conflicts of interest}

There are no conflicts to declare.

\section{Acknowledgements}

This work was funded by national funds through Fundação para a Ciência e a Tecnologia, Portugal (FCT) with the projects UIDB/04423/2020, UIDP/04423/2020, and PTDC/BIA-MIC/30131/2017 (NANOSED) also funded by the "Norte Portugal Regional Operational Programme" (Norte2020), under the PORTUGAL 2020 partnership agreement, through the European Regional Development Fund (ERDF). We would like to thank Eng. Paulo Faria for the opportunity to sample within the Nature Reserve of the Douro Estuary. 


\section{References}

1 J. R. Lead, G. E. Batley, P. J. J. Alvarez, M.-N. Croteau, R. D. Handy, M. J. McLaughlin, J. D. Judy and K. Schirmer, Nanomaterials in the environment: Behavior, fate, bioavailability, and effects-An updated review, Environ. Toxicol. Chem., 2018, 37, 2029-2063.

2 A. A. Keller, A. S. Adeleye, J. R. Conway, K. L. Garner, L. Zhao, G. N. Cherr, J. Hong, J. L. GardeaTorresdey, H. A. Godwin, S. Hanna, Z. Ji, C. Kaweeteerawat, S. Lin, H. S. Lenihan, R. J. Miller, A. E. Nel, J. R. Peralta-Videa, S. L. Walker, A. A. Taylor, C. Torres-Duarte, J. I. Zink and N. Zuverza-Mena, Comparative environmental fate and toxicity of copper nanomaterials, Nanolmpact, 2017, 7, 2840.

3 J. L. Gardea-Torresdey, C. M. Rico and J. C. White, Trophic Transfer, Transformation, and Impact of Engineered Nanomaterials in Terrestrial Environments, Environ. Sci. Technol., 2014, 48, 25262540.

4 A. S. Adeleye, E. A. Oranu, M. Tao and A. A. Keller, Release and detection of nanosized copper from a commercial antifouling paint, Water Res., 2016, 102, 374-382.

5 M. Kah, N. Tufenkji and J. C. White, Nano-enabled strategies to enhance crop nutrition and protection, Nat. Nanotechnol., 2019, 14, 532-540.

6 A. Lazareva and A. A. Keller, Estimating Potential Life Cycle Releases of Engineered Nanomaterials from Wastewater Treatment Plants, ACS Sustain. Chem. Eng., 2014, 2, 1656-1665.

7 T. Ameh and C. M. Sayes, The potential exposure and hazards of copper nanoparticles: A review, Environ. Toxicol. Pharmacol., 2019, 71, 103220.

8 J. R. Conway, A. S. Adeleye, J. Gardea-Torresdey and A. A. Keller, Aggregation, Dissolution, and Transformation of Copper Nanoparticles in Natural Waters, Environ. Sci. Technol., 2015, 49, 27492756.

9 K. L. Garner and A. A. Keller, Emerging patterns for engineered nanomaterials in the environment: a review of fate and toxicity studies, J. Nanoparticle Res., 2014, 16, 2503.

10 A. Castro-Bugallo, Á. González-Fernández, C. Guisande and A. Barreiro, Comparative Responses to Metal Oxide Nanoparticles in Marine Phytoplankton, Arch. Environ. Contam. Toxicol., 2014, 67, 483-493.

11 G. K. Bielmyer-Fraser, T. A. Jarvis, H. S. Lenihan and R. J. Miller, Cellular Partitioning of Nanoparticulate versus Dissolved Metals in Marine Phytoplankton, Environ. Sci. Technol., 2014, 48, 13443-13450.

12 M. S. Baptista, R. J. Miller, E. R. Halewood, S. K. Hanna, C. M. R. Almeida, V. M. Vasconcelos, A. A. Keller and H. S. Lenihan, Impacts of Silver Nanoparticles on a Natural Estuarine Plankton Community, Environ. Sci. Technol., 2015, 49, 12968-12974.

13 K. Proulx and K. J. Wilkinson, Separation, detection and characterisation of engineered nanoparticles in natural waters using hydrodynamic chromatography and multi-method detection (light scattering, analytical ultracentrifugation and single particle ICP-MS), Environ. Chem., 2014, 11, 392.

14 B. Giese, F. Klaessig, B. Park, R. Kaegi, M. Steinfeldt, H. Wigger, A. von Gleich and F. Gottschalk, Risks, Release and Concentrations of Engineered Nanomaterial in the Environment, Sci. Rep., 2018, 8, 1565.

15 M. J. Sullivan, A. J. Gates, C. Appia-Ayme, G. Rowley and D. J. Richardson, Copper control of bacterial nitrous oxide emission and its impact on vitamin B12-dependent metabolism, Proc. Natl. Acad. Sci., 2013, 110, 19926-19931.

16 C. Magalhães, J. Costa, C. Teixeira and A. A. Bordalo, Impact of trace metals on denitrification in estuarine sediments of the Douro River estuary, Portugal, Mar. Chem., 2007, 107, 332-341.

17 C. M. Magalhães, A. Machado, P. Matos and A. A. Bordalo, Impact of copper on the diversity, abundance and transcription of nitrite and nitrous oxide reductase genes in an urban European estuary: Impact of copper on denitrifier diversity and function, FEMS Microbiol. Ecol., 2011, 77, 274-284. 
18I. Iglesias, C. M. R. Almeida, C. Teixeira, A. P. Mucha, A. Magalhães, A. Bio and L. Bastos, Linking contaminant distribution to hydrodynamic patterns in an urban estuary: The Douro estuary test case, Sci. Total Environ., 2020, 707, 135792.

19 APDL, http://douro.apdl.pt/f?p=100:7:5882038318828 (accessed May 2020)

20 A. P. Mucha, M. T. S. D. Vasconcelos and A. A. Bordalo, Spatial and seasonal variations of the macrobenthic community and metal contamination in the Douro estuary (Portugal), Mar. Environ. Res., 2005, 60, 531-550.

21 M. E. C. Vieira and A. A. Bordalo, The Douro estuary (Portugal): a mesotidal salt wedge, Oceanol. Acta, 2000, 23, 585-594.

22 M. J. Costello, K. H. Beard, R. T. Corlett, G. S. Cumming, V. Devictor, R. Loyola, B. Maas, A. J. Miller-Rushing, R. Pakeman and R. B. Primack, Field work ethics in biological research, Biol. Conserv., 2016, 203, 268-271.

23 ISO 11465:1993 Soil quality - Determination of dry matter and water content on a mass basis Gravimetric method

24 C. M. Magalhäes, W. J. Wiebe, S. B. Joye and A. A. Bordalo, Inorganic nitrogen dynamics in intertidal rocky biofilms and sediments of the Douro River estuary (Portugal), Estuaries, 2005, 28, 592-607.

25 ISO/TS 14256-1:2003 Soil quality - Determination of nitrate, nitrite and ammonium in field-moist soils by extraction with potassium chloride solution -- Part 1: Manual method

26 M. S. Baptista, V. M. Vasconcelos and M. T. S. D. Vasconcelos, Trace Metal Concentration in a Temperate Freshwater Reservoir Seasonally Subjected to Blooms of Toxin-Producing Cyanobacteria, Microb. Ecol., 2014, 68, 671-678.

27 C. T. Rueden, J. Schindelin, M. C. Hiner, B. E. DeZonia, A. E. Walter, E. T. Arena and K. W. Eliceiri, ImageJ2: ImageJ for the next generation of scientific image data, BMC Bioinformatics, 2017, 18, 529.

28 J. P. Santos, D. Mendes, M. Monteiro, H. Ribeiro, M. S. Baptista, M. T. Borges and C. Magalhães, Salinity impact on ammonia oxidizers activity and amoA expression in estuarine sediments, Estuar. Coast. Shelf Sci., 2018, 211, 177-187.

29 W. Wei, K. Isobe, T. Nishizawa, L. Zhu, Y. Shiratori, N. Ohte, K. Koba, S. Otsuka and K. Senoo, Higher diversity and abundance of denitrifying microorganisms in environments than considered previously, ISME J., 2015, 9, 1954-1965.

30 S. Henry, D. Bru, B. Stres, S. Hallet and L. Philippot, Quantitative Detection of the nosZ Gene, Encoding Nitrous Oxide Reductase, and Comparison of the Abundances of $16 \mathrm{~S}$ rRNA, narG, nirk, and nosZ Genes in Soils, Appl. Environ. Microbiol., 2006, 72, 5181-5189.

31 G. Muyzer, E. C. de Waal and A. G. Uitterlinden, Profiling of complex microbial populations by denaturing gradient gel electrophoresis analysis of polymerase chain reaction-amplified genes coding for $16 \mathrm{~S}$ rRNA, Appl. Environ. Microbiol., 1993, 59, 695-700.

$32 \mathrm{~J}$. S. Yuan, A. Reed, F. Chen and C. N. Stewart, Statistical analysis of real-time PCR data, BMC Bioinformatics, 2006, 7, 85.

33 K. J. Livak and T. D. Schmittgen, Analysis of Relative Gene Expression Data Using Real-Time Quantitative PCR and the 2- $\Delta \Delta C T$ Method, Methods, 2001, 25, 402-408.

34 J. Quackenbush, Microarray data normalization and transformation, Nat. Genet., 2002, 32, 496501.

35 F. Bonk, D. Popp, H. Harms and F. Centler, PCR-based quantification of taxa-specific abundances in microbial communities: Quantifying and avoiding common pitfalls, J. Microbiol. Methods, 2018, 153, 139-147.

36 S. A. Bustin, V. Benes, J. A. Garson, J. Hellemans, J. Huggett, M. Kubista, R. Mueller, T. Nolan, M. W. Pfaffl, G. L. Shipley, J. Vandesompele and C. T. Wittwer, The MIQE Guidelines: Minimum Information for Publication of Quantitative Real-Time PCR Experiments, Clin. Chem., 2009, 55, 611-622. 
37 P. M. Groffman, M. A. Altabet, J. K. Böhlke, K. Butterbach-Bahl, M. B. David, M. K. Firestone, A. E. Giblin, T. M. Kana, L. P. Nielsen and M. A. Voytek, Methods for measuring denitrification: diverse approaches to a difficult problem, Ecol. Appl., 2006, 16, 2091-2122.

$38 \mathrm{R}$ Core Team, R: A language and environment for statistical computing, R Foundation for Statistical Computing, Vienna, Austria, 2017, http://www.R-project.org/.

$39 \mathrm{H}$. Wickham, tidyverse: easily install and load the 'Tidyverse', R package version 1.2.1, 2017, https://CRAN.R-project.org/package=tidyverse.

$40 \mathrm{H}$. Wickham, ggplot2: elegant graphics for data analysis, Springer-Verlang, New York, 2016.

41 C.O. Wilke, cowplot: Streamlined plot theme and plot annotations for 'ggplot2', R package version 1.0.0.,2019, https://CRAN.R-project.org/package=cowplot.

$42 \mathrm{H}$. Wickham and D. Seidel, scales: scale functions for visualization. R package version 1.1.0, 2019, https://CRAN.R-project.org/package=scales.

43 QGIS Development Team, QGIS Geographic Information System, Open Source Geospatial Foundation,2019, URL http://qgis.org.

44 E. Pebesma, Simple features for R: standardized support for spatial vector data, The R Journal,2018,10,439-446.

45 D. Dunnington, ggspatial: Spatial data framework for ggplot2, R package version 1.0.3, 2018, https://CRAN.R-project.org/package=ggspatial.

$46 \mathrm{~J}$. Ho, T. Tumkaya, S. Aryal, H. Choi and A. Claridge-Chang, Moving beyond P values: data analysis with estimation graphics, Nat. Methods, 2019, 16, 565-566.

47 J. Oksanen, F. G. Blanchet, M. Friendly, R. Kindt, P. Legendre, D. McGlinn, P. R. Minchin, R. B. O'Hara, G. L. Simpson, P. Solymos, M. H. H. Stevens, E. Szoecs and H. Wagner, vegan: Community Ecology Package, R package version 2.5-5, 2017, https://CRAN.R-project.org/package=vegan.

48 P. L. Buttigieg and A. Ramette, A guide to statistical analysis in microbial ecology: a communityfocused, living review of multivariate data analyses, FEMS Microbiol. Ecol., 2014, 90, 543-550.

$49 \mathrm{M}$. J. Anderson and D. C. I. Walsh, PERMANOVA, ANOSIM, and the Mantel test in the face of heterogeneous dispersions: What null hypothesis are you testing?, Ecol. Monogr., 2013, 83, 557574.

50 M. Yang, D. Xue, F. Meng and Z.-L. Wang, The effects of salinity on coupled nitrification and aerobic denitrification in an estuarine system, Water Sci. Technol., 2015, 71, 1718-1726.

51 J. A. Acosta, B. Jansen, K. Kalbitz, A. Faz and S. Martínez-Martínez, Salinity increases mobility of heavy metals in soils, Chemosphere, 2011, 85, 1318-1324.

$52 \mathrm{~S}$. Zhao, C. Feng, D. Wang, Y. Liu and Z. Shen, Salinity increases the mobility of $\mathrm{Cd}, \mathrm{Cu}, \mathrm{Mn}$, and $\mathrm{Pb}$ in the sediments of Yangtze Estuary: Relative role of sediments' properties and metal speciation, Chemosphere, 2013, 91, 977-984.

53 C. M. R. Almeida, A. P. Mucha and M. T. S. D. Vasconcelos, Influence of the Sea Rush Juncus maritimus on Metal Concentration and Speciation in Estuarine Sediment Colonized by the Plant, Environ. Sci. Technol., 2004, 38, 3112-3118.

54 L. Philippot, J. Čuhel, N. P. A. Saby, D. Chèneby, A. Chroňáková, D. Bru, D. Arrouays, F. MartinLaurent and M. Šimek, Mapping field-scale spatial patterns of size and activity of the denitrifier community, Environ. Microbiol., 2009, 11, 1518-1526.

55 D. Helen, H. Kim, B. Tytgat and W. Anne, Highly diverse nirk genes comprise two major clades that harbour ammonium-producing denitrifiers, BMC Genomics, 2016, 17, 155.

$56 \mathrm{~J}$. A. Lee and C. A. Francis, Spatiotemporal Characterization of San Francisco Bay Denitrifying Communities: a Comparison of nirK and nirS Diversity and Abundance, Microb. Ecol., 2017, 73, 271-284.

57 C. M. Jones, B. Stres, M. Rosenquist and S. Hallin, Phylogenetic Analysis of Nitrite, Nitric Oxide, and Nitrous Oxide Respiratory Enzymes Reveal a Complex Evolutionary History for Denitrification, Mol. Biol. Evol., 2008, 25, 1955-1966. 
58 J. P. Malone, R. J. Stevens and R. J. Laughlin, Combining the $15 \mathrm{~N}$ and acetylene inhibition techniques to examine the effect of acetylene on denitrification, Soil Biol. Biochem., 1998, 30, 3137.

59 C. Teixeira, C. Magalhães, R. A. R. Boaventura and A. A. Bordalo, Potential rates and environmental controls of denitrification and nitrous oxide production in a temperate urbanized estuary, Mar. Environ. Res., 2010, 70, 336-342.

60 M. Holtappels, G. Lavik, M. M.Jensen and M. M. M. Kuypers, $15 \mathrm{~N}$-labeling experiments to dissect the contributions of heterotrophic denitrification and anammox to nitrogen removal in the $\mathrm{OMZ}$ waters of the ocean. Method. Enzymol., 2011, 486, 223-251.

61 C. Teixeira, C. Magalhães, S. B. Joye and A. A. Bordalo, Response of anaerobic ammonium oxidation to inorganic nitrogen fluctuations in temperate estuarine sediments: ANAMMOX RESPONSE TO N FLUCTUATIONS, J. Geophys. Res. Biogeosciences, 2016, 121, 1829-1839.

62 C. Kaweeteerawat, C. H. Chang, K. R. Roy, R. Liu, R. Li, D. Toso, H. Fischer, A. Ivask, Z. Ji, J. I. Zink, Z. H. Zhou, G. F. Chanfreau, D. Telesca, Y. Cohen, P. A. Holden, A. E. Nel and H. A. Godwin, Cu Nanoparticles Have Different Impacts in Escherichia coli and Lactobacillus brevis than Their Microsized and Ionic Analogues, ACS Nano, 2015, 9, 7215-7225.

63 European Commission, https://ec.europa.eu/environment/chemicals/nanotech/faq/definition_en.htm (accessed May 2020).

64 F. Gottschalk, C. Lassen, J. Kjoelholt, F. Christensen and B. Nowack, Modeling Flows and Concentrations of Nine Engineered Nanomaterials in the Danish Environment, Int. J. Environ. Res. Public. Health, 2015, 12, 5581-5602.

$65 \mathrm{G}$. Wu, X. Zhai, C. Jiang and Y. Guan, Denitrifying kinetics and nitrous oxide emission under different copper concentrations, Water Sci. Technol., 2014, 69, 746-754.

66 A. Messerschmidt, in Comprehensive Natural Products II, Elsevier, 2010, pp. 489-545.

67 D. R. H. Graf, C. M. Jones and S. Hallin, Intergenomic Comparisons Highlight Modularity of the Denitrification Pathway and Underpin the Importance of Community Structure for N2O Emissions, PLOS ONE, 2014, 9, e114118.

68 R. Bartossek, G. W. Nicol, A. Lanzen, H.-P. Klenk and C. Schleper, Homologues of nitrite reductases in ammonia-oxidizing archaea: diversity and genomic context: Nitrite reductase of soil archaea, Environ. Microbiol., 2010, 12, 1075-1088.

69 Y. Ma, J. L. Zilles and A. D. Kent, An evaluation of primers for detecting denitrifiers via their functional genes, Environ. Microbiol., 2019, 21, 1196-1210.

70 E. J. Raes, K. Karsh, A. J. Kessler, P. L. M. Cook, B. H. Holmes, J. van de Kamp, L. Bodrossy and A. Bissett, Can We Use Functional Genetics to Predict the Fate of Nitrogen in Estuaries?, Front. Microbiol., 2020, 11, 1261.

$71 \mathrm{~J}$. Granger and B. B. Ward, Accumulation of nitrogen oxides in copper-limited cultures of denitrifying bacteria, Limnol. Oceanogr., 2003, 48, 313-318.

72 A. Black, P.-C. L. Hsu, K. E. Hamonts, T. J. Clough and L. M. Condron, Influence of copper on expression of nirS, norB and nosZ and the transcription and activity of NIR, NOR and $\mathrm{N}_{2}$ OR in the denitrifying soil bacteria Pseudomonas stutzeri, Microb. Biotechnol., 2016, 9, 381-388.

73 R. W. Portmann, J. S. Daniel and A. R. Ravishankara, Stratospheric ozone depletion due to nitrous oxide: influences of other gases, Philos. Trans. R. Soc. B Biol. Sci., 2012, 367, 1256-1264.

$74 \mathrm{H}$. Tian, M. Kah and K. Kariman, Are Nanoparticles a Threat to Mycorrhizal and Rhizobial Symbioses? A Critical Review, Front. Microbiol., 2019, 10, 1660. 
Table 1. Water and sediment characteristics at the time of sampling

\begin{tabular}{|c|c|c|c|}
\hline & Sampling & EXP1 & EXP2 \\
\hline & Date & 08/01/2019 & $15 / 01 / 2019$ \\
\hline & \multicolumn{3}{|l|}{ In situ data } \\
\hline \multirow{6}{*}{$\begin{array}{l}\stackrel{ \pm}{ \pm} \\
\stackrel{\pi}{3}\end{array}$} & Temperature $\left({ }^{\circ} \mathrm{C}\right)$ & 20 & 13 \\
\hline & Salinity (psu) & 21 & 9 \\
\hline & Conductivity (mS/cm) & 34 & 15 \\
\hline & Dissolved $\mathrm{O}_{2}(\mathrm{mg} / \mathrm{L})$ & 5.9 & 7.1 \\
\hline & $\mathrm{pH}$ & 8.3 & 8.8 \\
\hline & Laboratory data & & \\
\hline \multirow{3}{*}{$\begin{array}{l}\frac{1}{ \pm} \\
\frac{ \pm}{3} \\
3\end{array}$} & $\mathrm{~N}-\mathrm{NO}_{3}^{-}(\mu \mathrm{mol} / \mathrm{L})$ & 42.0 & 60.9 \\
\hline & $\mathrm{N}-\mathrm{NO}_{2}^{-}(\mu \mathrm{mol} / \mathrm{L})$ & 0.16 & 0.20 \\
\hline & $\mathrm{N}-\mathrm{NH}_{4}^{-}(\mu \mathrm{mol} / \mathrm{L})$ & 4.37 & 12.3 \\
\hline \multirow{9}{*}{ 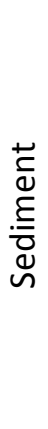 } & $\mathrm{N}-\mathrm{NO}_{3}^{-}(\mu \mathrm{mol} / \mathrm{mg})$ & 21.4 & 23.5 \\
\hline & $\mathrm{N}-\mathrm{NO}_{2}^{-}(\mu \mathrm{mol} / \mathrm{mg})$ & 7.75 & 6.31 \\
\hline & $\mathrm{N}-\mathrm{NH}_{4}^{-}(\mu \mathrm{mol} / \mathrm{mg})$ & 132 & 64.4 \\
\hline & Organic matter (\%) & 0.99 & 0.99 \\
\hline & Cu environmentally available ( $\mu \mathrm{g} / \mathrm{g})$ & 4.94 & 4.13 \\
\hline & Cu exchangeable $(\mu \mathrm{g} / \mathrm{g})$ & 0.13 & 0.11 \\
\hline & Fe environmentally available $(\mathrm{mg} / \mathrm{g})$ & 6.04 & 4.10 \\
\hline & Fe exchangeable (mg/g) & 0.07 & 0.07 \\
\hline & Cell number $\times 10^{9}$ (per g sediment) & 3.32 & 4.20 \\
\hline
\end{tabular}




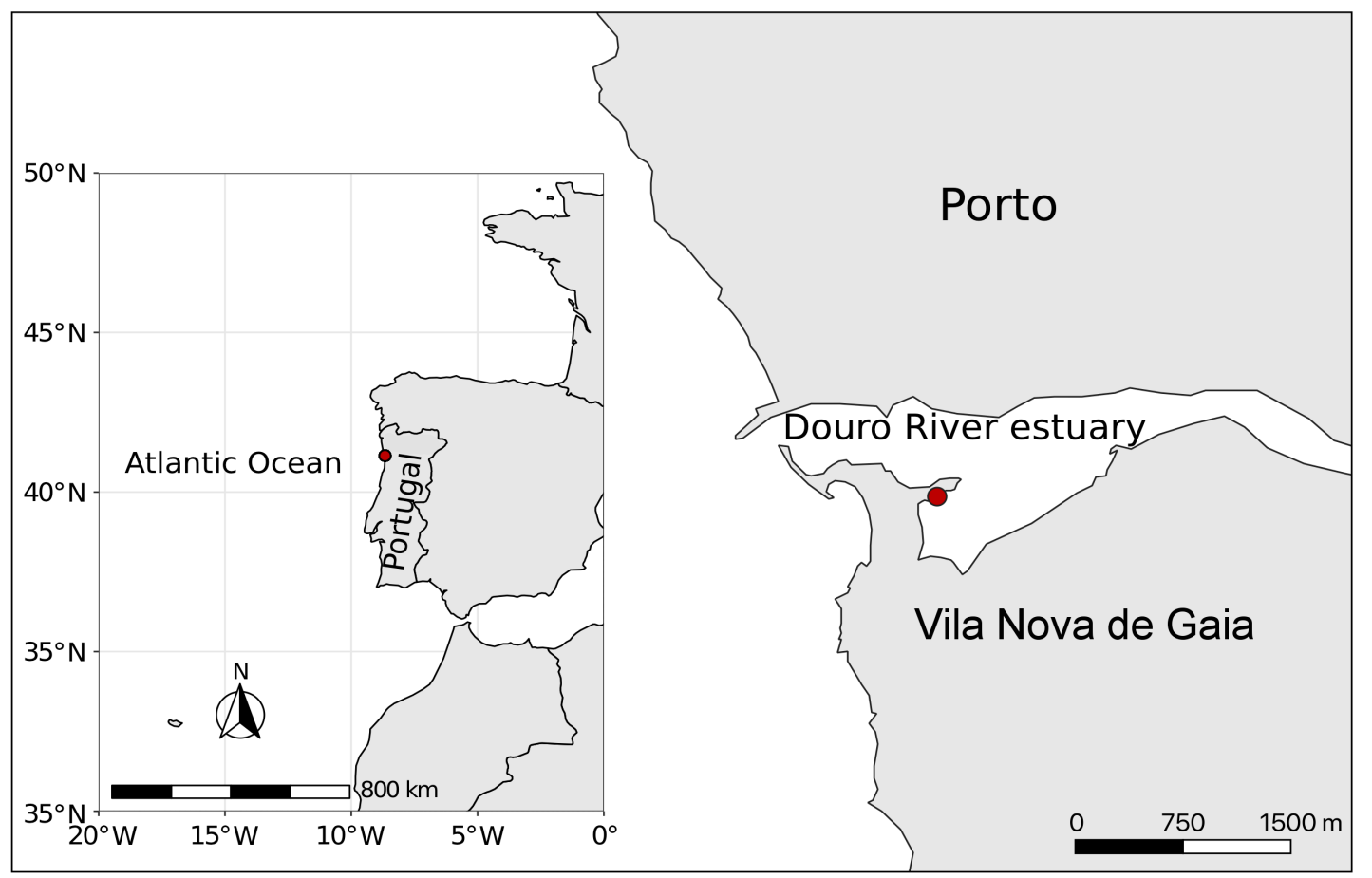

Fig. 1 Study area and sampling site. Map of the Douro river estuary detailing the location of the sampling site (red dot) and inset map of continental Portugal and the Atlantic Ocean, where Douro disembogues. 

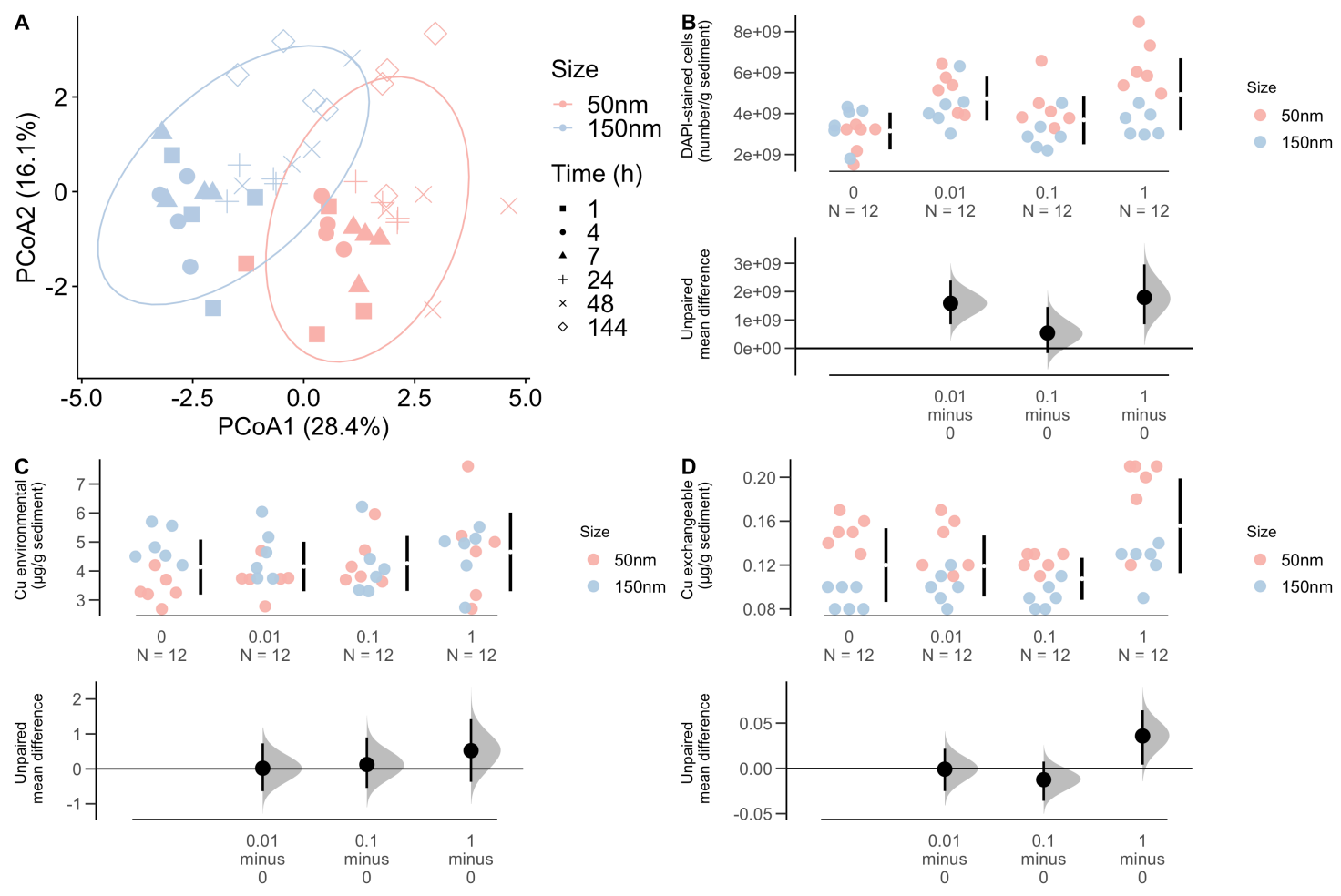

Fig. 2 Copper availability and cell numbers in the microcosms exposed to Cu NPs. A) Principal component analysis, with ellipses overlaid at a 0.95 level, showing the separation between the microcosms exposed to Cu NPs $<50 \mathrm{~nm}$ and $<150 \mathrm{~nm}$, particularly in the first $24 \mathrm{~h}$ of exposure; B) Number of bacteria (DAPI-stained cells) in the sediment; C) Cu concentration in the sediment environmentally available fraction and $\mathbf{D}$ ) in the sediment exchangeable fraction. In the estimation plots (B-D) results are reported for microcosms exposed to Cu NPs $0,0.01,0.1$ and $1 \mu \mathrm{g} \mathrm{g}^{-1}$. Gapped lines to the right of each concentration group are mean value \pm standard deviation and the effect size, with $95 \%$ confidence intervals, is plotted below. 


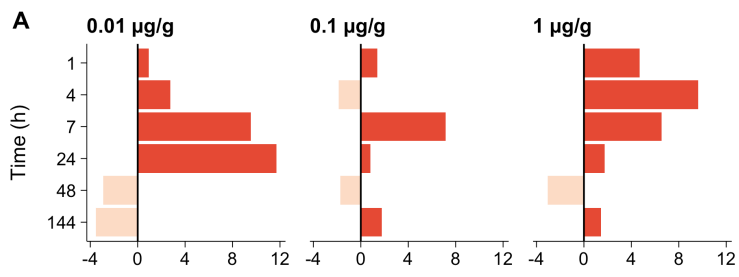

$\log _{2}$ fold-change in nirS transcripts

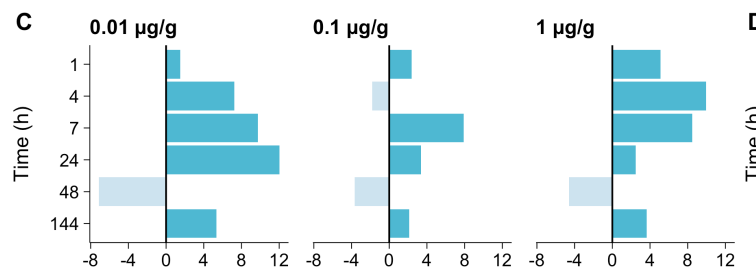

$\log _{2}$ (fold-change) in nos $Z$ transcripts

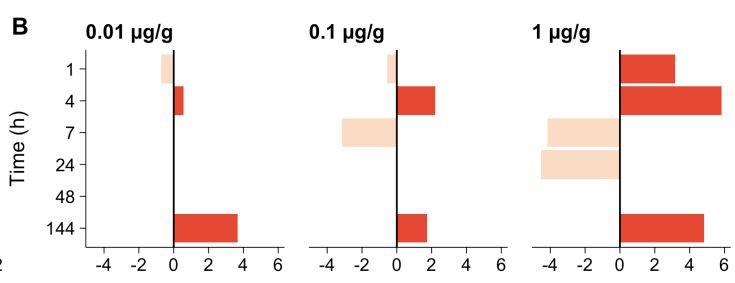

$\log _{2}$ (fold-change) in nirS transcripts

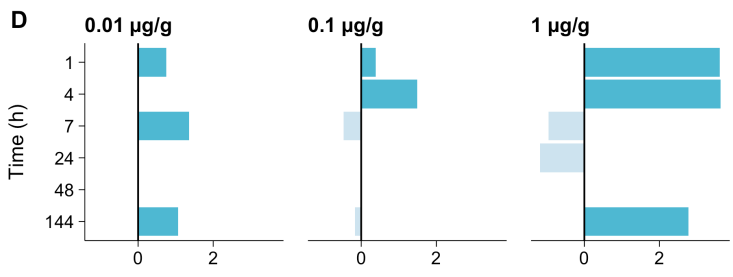

$\log _{2}$ (fold-change) in nosZ transcripts

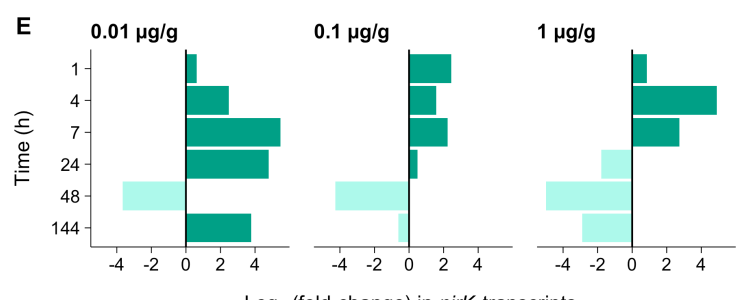

$\log _{2}$ (fold-change) in nirK transcripts

Fig. 3 Changes in gene expression in microcosms exposed to Cu NPs. Relative quantification was determined by fold changes in expression of A) nirS transcripts in microcosms exposed to Cu NPs $<$ $50 \mathrm{~nm}$; B) nirS transcripts in microcosms exposed to Cu NPs $<150 \mathrm{~nm}$; C) nosZ transcripts in microcosms exposed to Cu NPs $<50 \mathrm{~nm}$; D) nosZ transcripts in microcosms exposed to Cu NPs $<150$ $\mathrm{nm}$; E) nirk transcripts in microcosms exposed to Cu NPs $<50 \mathrm{~nm}$. Fold change in gene expression is the average of two replicates; RSD between replicates varied between 3 and $17 \%$. 
A
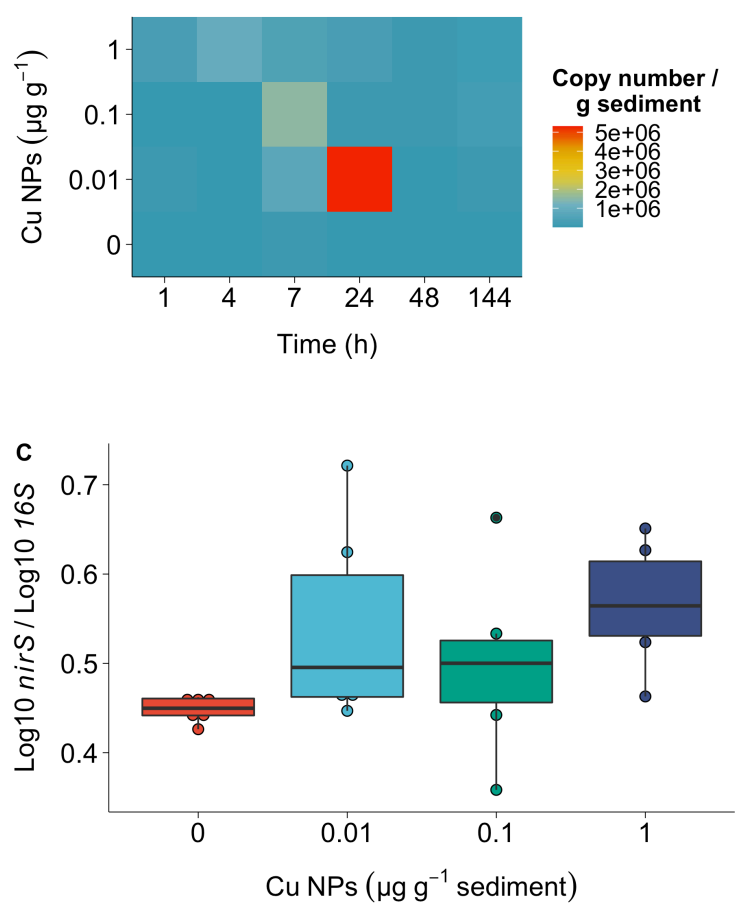

B
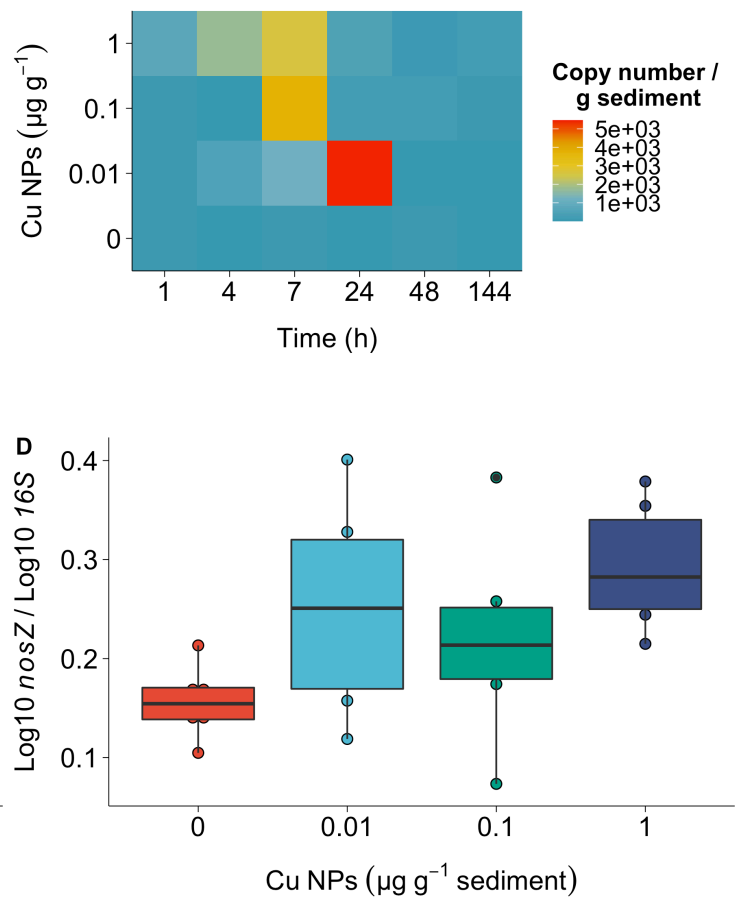

Fig. 4 Abundance of denitrification genes in microcosms exposed to $\mathrm{Cu}$ NPs $<50 \mathrm{~nm}$. Absolute quantification of gene copy number per gram dry sediment is shown during the time-course experiment as a heatmap for A) nirS and B) nosZ; and shown for the different concentrations tested as a boxplot for $\mathbf{C}$ ) nirS and D) nosZ with gene copy number per gram dry sediment log10 transformed, and nirS and nosZ values normalized by the 165 rRNA gene. 

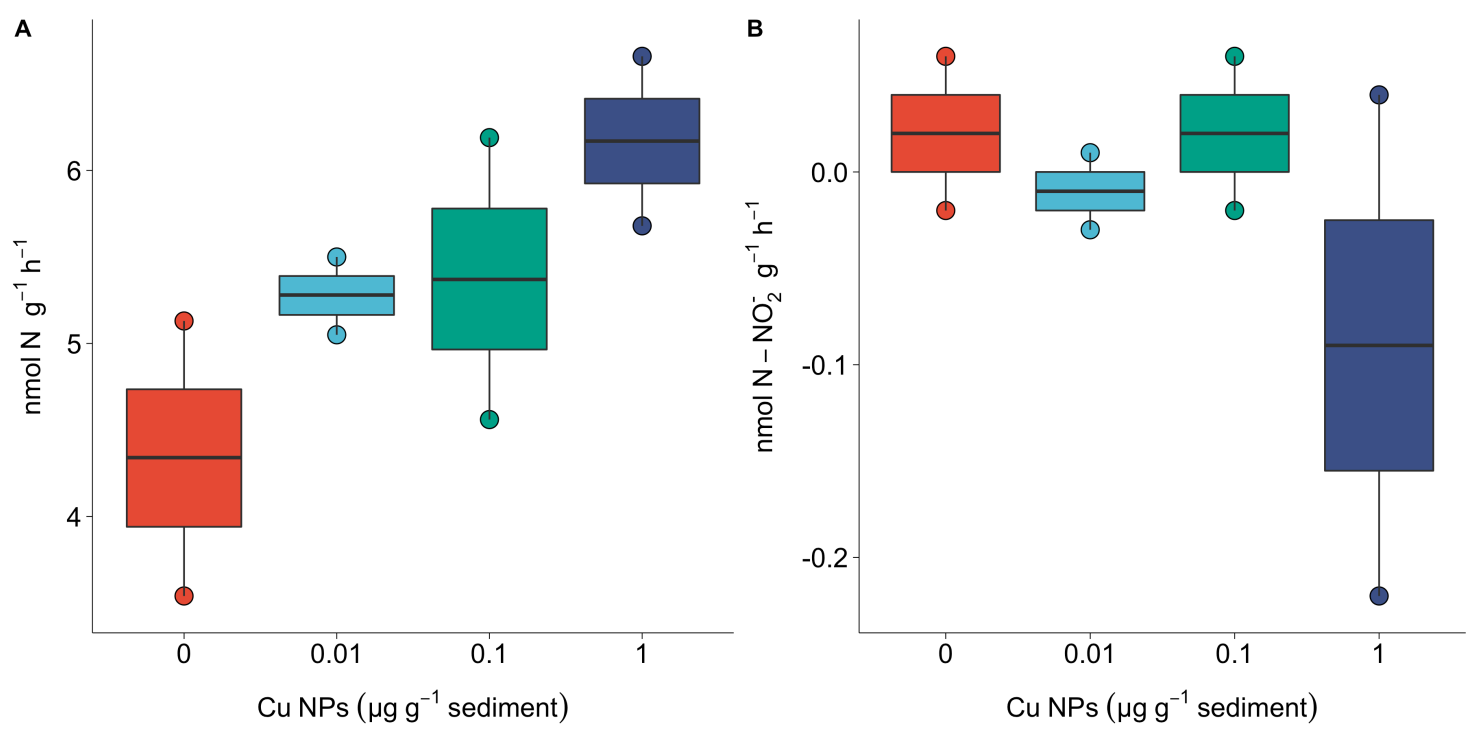

Fig. 5 Potential denitrification and $\mathrm{N}^{-\mathrm{NO}_{2}}{ }^{-}$consumption on the sediments exposed to $\mathrm{Cu} \mathrm{NPs}<50$

nm. A) Potential denitrification rates were calculated from the difference in $\mathrm{N}_{2} \mathrm{O}$ produced with and without $\mathrm{C}_{2} \mathrm{H}_{2}$, over time; and $\left.\mathbf{B}\right) \mathrm{N}-\mathrm{NO}_{2}{ }^{-}$consumption rates were determine by the slopes of the linear regressions of concentration over time. 


\section{Supplementary Information}

\section{Copper nanoparticles prompt the activity of estuarine denitrifying bacterial communities at relevant environmental concentrations}

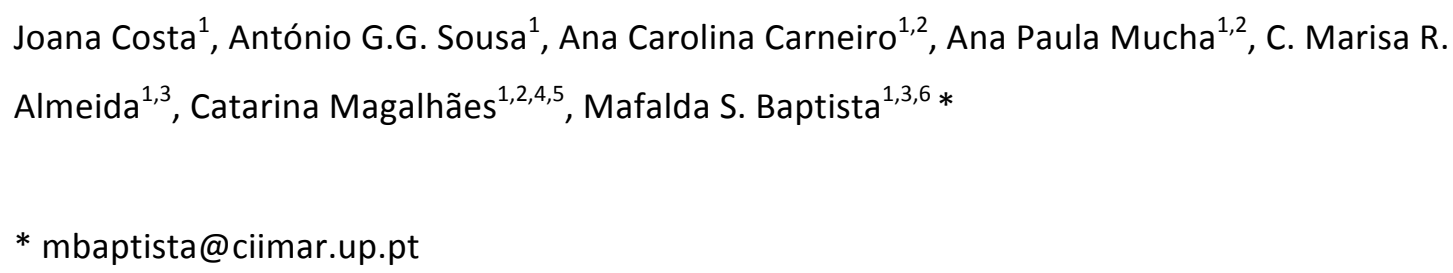

${ }^{1}$ CIIMAR/CIMAR - Centro Interdisciplinar de Investigação Marinha e Ambiental, Universidade do Porto, Matosinhos, Portugal

${ }^{2}$ Departamento de Biologia, Faculdade de Ciências, Universidade do Porto, Porto, Portugal

${ }^{3}$ Departamento de Química e Bioquímica, Faculdade de Ciências, Universidade do Porto, Porto, Portugal

${ }^{4}$ School of Science, University of Waikato, Hamilton, New Zealand

${ }^{5}$ Ocean Frontier Institute, Dalhousie University, Canada

${ }^{6}$ International Centre for Terrestrial Antarctic Research, University of Waikato, Hamilton, New Zealand

\section{Supplementary Experimental}

\section{Selection of primers targeting nitrite and nitrous oxide reductase genes}

Both nitrite (nir) and nitrous oxide (nosZ) reductase genes have been shown to exhibit phylogenetic distinct Clades and to harbour taxonomically diverse microorganisms. ${ }^{1-4}$ This has posed challenges to the design of primers that are both unambiguous and comprehensive of the denitrifier diversity. Common primers for nitrite reductase nirK gene are $\mathrm{F} 1 \mathrm{aCu} / \mathrm{R}_{3} \mathrm{Cu}{ }^{5}$ and nirK2F/nirK5R; ${ }^{6}$ for nirS gene are $\mathrm{cd} 3 \mathrm{aF} / \mathrm{R} 3 \mathrm{~cd}^{7,8}$ and nirS2F/nirS4R. ${ }^{6}$ At the time these were designed the sequences available were mostly from Proteobacteria strains, which 
narrowed the diversity of these genes to this taxon. Nowadays they are still commonly used but advances in culture-independent methods to investigate the microbial community composition allowed the identification of nir genes across diverse taxonomic groups. A recent revision grouped nir genes into four Clusters for nirk gene and three Clusters for nirS. ${ }^{2}$ The previously described primers only target nirk and nirS in Cluster I, and to address this issue the authors have designed specific primers for each Cluster. ${ }^{2}$

The nos $Z$ gene primers nos $Z 2 F / n o s Z 2 R{ }^{9}$ have been designed to be as universal as possible, and in spite of its potential bias against gram-positive bacteria they have been widely used ever since. More recently nosZ have been grouped into two different Clades. Clade I consisted mostly in Proteobacteria sequences following the species phylogeny as previously observed, and Clade II consisted of sequences found among a diverse range of bacterial and archaeal phyla. ${ }^{4}$ Moreover, nosZ in Clade II has since been recognized as one comprising atypical nitrous oxide reducers found in various ecosystems. ${ }^{10}$

In order to choose the primers with the widest coverage for our study, we carried out an in silico analysis based on a microbial diversity assessment (16S rRNA gene) previously performed at the same sampling site of Douro estuary. ${ }^{11}$ Prokaryotic OTUs were categorized based on the presence of the functional genes within genomes that coded for proteins in the denitrification pathway, as compiled and reported before for $n i r^{2}$ and nosz. ${ }^{4}$

The analysis showed bacterial OTUs predominantly affiliated with genera showing nosZ in Clade I (Table S1). For this reason the primer pair nosZ2F/nosZ2R was chosen for this study, based on the intuition that the primer set yielding the greater diversity would be the most suitable one. ${ }^{9}$ Denitrifying OTUs were affiliated with Bacteria genera showing nirK in Cluster I and II, however, for nirS only OTUs affiliated with Bacteria genera showing nirS in Cluster I could be predicted (Table S1). As expected, we found that OTUs affiliated with genera that could potentially harbour nirS were much more abundant than OTUs affiliated with genera that could harbour nirk (relative abundances of $1.3 \%$ and $0.2 \%$, respectively). ${ }^{12,13}$ The most commonly used primers were designed for nirS and nirK in Cluster I because for several environments they are the most ubiquitous and abundant. This was the case for nirs, and preliminary tests in our samples showed that using primers nirSC1F/nirSC1R for nirS in Cluster I resulted in amplification (assessed by loading the PCR product in an agarose gel). Therefore, these primers were chosen for this study. Contrary to what was expected, at Douro estuary nirk in Cluster II was more abundant than in Cluster I. To confirm this assumption we tried to amplified our samples using primers nirKC1F/nirKC1R and nirKC2F/nirKC2R and nirK in Cluster 
II was the only for which we could see amplification (assessed by loading the PCR product in an agarose gel). Therefore, we chose primers nirKC2F/nirKC2R for this study.

For Archaea, Nitrosopumilus sp., a genus potentially containing nirk homologous genes, ${ }^{14}$ was found at Douro estuary. However, Archaea represented only $0.7 \%$ of the OTUs at our sampling site. Specific primers have been designed for targeting the archaeal nirk, and although its transcription potential has been shown, no significant increase in transcript copy number was observed with increased denitrifying activity. ${ }^{14}$ For these reasons we chose not to include these primers in the present study.

\section{Positive controls for the genes of interest}

Bacteria Roseobacter denitrificans (obtained from the DSMZ-German Collection of Microorganisms and Cell Cultures $\mathrm{GmbH}$ ) was used as positive control for nirS in Cluster I and for nosZ, and Fulvivirga imtechensis AK7 (obtained from the Japan Collection of Microorganisms) was used as positive control for nirk in Cluster II. These strains were chosen after an in silico PCR was performed by retrieving the sequences of the genes of interest annotated in UniProtKB (https://www.uniprot.org/) for these strains, and uploading it in Serial Cloner 2.6 (http://serialbasics.free.fr/Serial_Cloner.html) to align with the primers. Both strains were grown in marine agar medium (3\%) for 2 - 3 days, at room temperature. DNA was extracted with the E.Z.N.A. Bacterial DNA Kit (Omega Bio-tek) and the genes were amplified in a PCR reaction on a Veriti Thermal Cycler (Applied Biosystems) performed with 12.5 $\mu \mathrm{L}$ of DreamTaq PCR Master Mix (Thermo Scientific), with primers at a concentration of 1 $\mu \mathrm{mol} \mathrm{L} \mathrm{L}^{-1}$ and 25 - $50 \mathrm{ng}$ of DNA template, in a final volume of $25 \mu \mathrm{L}$. The primers are described in Table S2 and the thermal cycler conditions were as described in previous works for nirk, ${ }^{2}$ nirs, ${ }^{15}$ nosZ. ${ }^{9}$ PCR products of duplicate reactions were pooled together and the bands with the expected size - 457 bp for nirk, 425 bp for nirS, 267 bp for nosZ - were excised from an agarose gel (1.5\%), under UV light, with the QIAquick Gel Extraction Kit (QIAGEN). The excised bands were sequenced with Sanger sequencing technology at STAB VIDA (Porto, Portugal). The nirs gene was sequenced only in the forward direction (due to low sample volume) and the remaining genes were sequencing in both forward and reverse directions. Forward and reverse sequences were assembled with the CAP3 software, ${ }^{16}$ embedded into the Unipro UGENE software (Linux 64-bit version 1.32). ${ }^{17}$ The consensus sequences were then confirmed by blast searches against UniprotKB (accessed on 24/11/2019) using the blastx algorithm (http://www.ncbi.nlm.nih.gov). ${ }^{18}$ 


\section{Absolute and relative quantification of gene expression levels}

Reverse transcription quantitative real-time PCR (RT-qPCR) was performed using $6 \mathrm{ng}$ of cDNA for $16 S$ rRNA, nirS and nosZ in a StepOnePlus real-time PCR System (Applied Biosystems) using Power SYBR Green PCR Master Mix (ThermoFisher Scientific). Relative quantification of gene expression levels was obtained by serial dilution of cDNA pooled from eight microcosms samples which was used as standard to allow calculating the slope and correlation coefficients of the standard curve and the PCR efficiency (Table S2). For nirK the same conditions resulted in the inhibition of the PCR reaction. Diluting the cDNA samples to overcome the inhibition was proven successful by conventional PCR (assessed by loading the PCR product in an agarose gel) but the cDNA concentration after dilution was not enough for RT-qPCR amplification. The tested primers and thermal programs had been successful in amplifying nirK in Cluster II of $F$. imtechensis obtained after cloning and for that reason $6 \mathrm{ng}$ of DNA from microcosms samples was analysed for nirK relative expression. To quantify absolute numbers of copies PCR products of nirS and nosZ gene were obtained as described above for $R$. denitrificans. Additionally, R. denitrificans was also used to obtain PCR products of the $16 S$ rRNA gene using the primers described in Table $\mathrm{S} 2$ and thermocycler conditions described in a previous work. ${ }^{19}$ PCR products were cloned using the TOPO-TA cloning kit with pCR 2.1-TOPO and One Shot TOP10 Chemically Competent E. coli (Invitrogen - Thermo Fisher). Colonies developed for $10 \mathrm{~h}$ in solid medium (40 $\mathrm{g} \mathrm{L}^{-1} \mathrm{LB}$ Broth, ampicillin $50 \mathrm{\mu g} \mathrm{ml}^{-1}$ and X-gal 100 $\mathrm{mmol} \mathrm{L}^{-1}$ ) at $37^{\circ} \mathrm{C}$, and then selected plasmid-inserted colonies were grown overnight in liquid medium. Plasmids were isolated from this culture using GenElute Plasmid MiniPrep kit (Sigma-Aldrich). Confirmation of the correct gene fragments was done by Sanger sequencing and genes were amplified in a StepOnePlus real-time PCR System, as described above. A standard curve was constructed by plotting the quantification cycle $(\mathrm{Cq})$ versus the logarithm of the number of copies of the gene, assuming for standard DNA $660 \mathrm{~g} \mathrm{~mol}^{-1}$ and $6.022 \times 10^{23}$ bp mol ${ }^{-1} .{ }^{20} \mathrm{~A}$ correction for ploidy was introduced for $165 \mathrm{rRNA}$ following a search in $r$ rnDB database ${ }^{21}$ and considering an average of three $16 S$ rRNA operon copy number per genome. For nirS and nosZ a conservative approach (1 copy per organism) was considered, following a previous work listing organisms harbouring denitrification genes, with the respective copy numbers. ${ }^{12}$ 


\section{Supplementary Tables}

Table S1. Predicted OTU-containing nir and nosZ on the sediment microbial community of Douro estuary

\begin{tabular}{|c|c|c|c|c|c|c|c|c|c|c|c|}
\hline \multirow[t]{2}{*}{ Clade } & \multirow[t]{2}{*}{ OTU } & \multirow[t]{2}{*}{ Kingdom } & \multirow[t]{2}{*}{ Phyllum } & \multirow[t]{2}{*}{ Class } & \multirow[t]{2}{*}{ Order } & \multirow[t]{2}{*}{ Family } & \multirow[t]{2}{*}{ Genus } & \multirow{2}{*}{$\begin{array}{c}2014 \\
\text { Jun } \\
\end{array}$} & \multirow{2}{*}{$\begin{array}{c}2015 \\
\text { Jun }\end{array}$} & \multirow{2}{*}{$\begin{array}{c}2014 \\
\text { Dec } \\
\end{array}$} & \multirow{2}{*}{$\begin{array}{c}2015 \\
\text { Dec } \\
\end{array}$} \\
\hline & & & & & & & & & & & \\
\hline nirk I & C2_1511 & Bacteria & Proteobacteria & Rhizobiales & Bradyrhizobiaceae & Alphaproteobacteria & Bradyrhizobium & 0.00000 & 0.00000 & 0.00998 & 0.00000 \\
\hline nirk I & C2 4712 & Bacteria & Proteobacteria & Rhizobiales & Bradyrhizobiaceae & Alphaproteobacteria & Bradyrhizobium & 0.00000 & 0.00000 & 0.00998 & 0.00249 \\
\hline nirk II & C2_975 & Bacteria & Proteobacteria & Burkholderiales & Comamonadaceae & Betaproteobacteria & Acidovorax & 0.08072 & 0.11641 & 0.44897 & 0.23670 \\
\hline nirs I & A1_10994 & Bacteria & Proteobacteria & Pseudomonadales & Pseudomonadaceae & Gammaproteobacteria & Pseudomonas & 0.01883 & 0.03004 & 0.00998 & 0.01246 \\
\hline nirs I & A1_13628 & Bacteria & Proteobacteria & Pseudomonadales & Pseudomonadaceae & Gammaproteobacteria & Pseudomonas & 0.01883 & 0.04506 & 0.03991 & 0.05481 \\
\hline nirs I & A1_1863 & Bacteria & Proteobacteria & Rhodocyclales & Rhodocyclaceae & Betaproteobacteria & Azoarcus & 0.05919 & 0.03380 & 0.04989 & 0.06229 \\
\hline nirs I & A1_2344 & Bacteria & Proteobacteria & Pseudomonadales & Pseudomonadaceae & Gammaproteobacteria & Pseudomonas & 0.02153 & 0.03755 & 0.01995 & 0.02990 \\
\hline nirs I & A1_7747 & Bacteria & Proteobacteria & Rhodocyclales & Rhodocyclaceae & Betaproteobacteria & Azoarcus & 0.06727 & 0.07886 & 0.14966 & 0.09966 \\
\hline nirS I & A1_827 & Bacteria & Proteobacteria & Pseudomonadales & Pseudomonadaceae & Gammaproteobacteria & Pseudomonas & 0.82333 & 0.87123 & 1.27706 & 1.16604 \\
\hline nirs I & C2_1511 & Bacteria & Proteobacteria & Rhizobiales & Bradyrhizobiaceae & Alphaproteobacteria & Bradyrhizobium & 0.00000 & 0.00000 & 0.00998 & 0.00000 \\
\hline nirs I & C2_4712 & Bacteria & Proteobacteria & Rhizobiales & Bradyrhizobiaceae & Alphaproteobacteria & Bradyrhizobium & 0.00000 & 0.00000 & 0.00998 & 0.00249 \\
\hline nirs I & C2_9 & Bacteria & Proteobacteria & Rhodocyclales & Rhodocyclaceae & Betaproteobacteria & Dechloromonas & 0.00538 & 0.00751 & 0.00998 & 0.01495 \\
\hline nirs I & DA2_28640 & Bacteria & Proteobacteria & Pseudomonadales & Pseudomonadaceae & Gammaproteobacteria & Pseudomonas & 0.01345 & 0.02253 & 0.01995 & 0.05980 \\
\hline nosz I & A1_10994 & Bacteria & Proteobacteria & Pseudomonadales & Pseudomonadaceae & Gammaproteobacteria & Pseudomonas & 0.01883 & 0.03004 & 0.00998 & 0.01246 \\
\hline nosZI & A1_13628 & Bacteria & Proteobacteria & Pseudomonadales & Pseudomonadaceae & Gammaproteobacteria & Pseudomonas & 0.01883 & 0.04506 & 0.03991 & 0.05481 \\
\hline nosZI & A1_1635 & Bacteria & Proteobacteria & Alteromonadales & Alteromonadaceae & Gammaproteobacteria & Marinobacter & 0.15606 & 0.13519 & 0.16961 & 0.20181 \\
\hline nosZ I & A1_1863 & Bacteria & Proteobacteria & Rhodocyclales & Rhodocyclaceae & Betaproteobacteria & Azoarcus & 0.05919 & 0.03380 & 0.04989 & 0.06229 \\
\hline nosZI & A1_2344 & Bacteria & Proteobacteria & Pseudomonadales & Pseudomonadaceae & Gammaproteobacteria & Pseudomonas & 0.02153 & 0.03755 & 0.01995 & 0.02990 \\
\hline nosZI & A1_23555 & Bacteria & Proteobacteria & Rhodobacterales & Rhodobacteraceae & Alphaproteobacteria & Roseovarius & 0.08879 & 0.11266 & 0.07982 & 0.10464 \\
\hline nosZI & A1_25707 & Bacteria & Proteobacteria & Rhodobacterales & Rhodobacteraceae & Alphaproteobacteria & Roseovarius & 0.03767 & 0.02629 & 0.01995 & 0.03737 \\
\hline
\end{tabular}




\begin{tabular}{|c|c|c|c|c|c|c|c|c|c|c|c|}
\hline $\operatorname{nos} Z 1$ & A1_29855 & Bacteria & Proteobacteria & Rhodobacterales & Rhodobacteraceae & Alphaproteobacteria & Roseovarius & 0.01883 & 0.07135 & 0.04989 & 0.04236 \\
\hline $\operatorname{nos} Z 1$ & A1_7747 & Bacteria & Proteobacteria & Rhodocyclales & Rhodocyclaceae & Betaproteobacteria & Azoarcus & 0.06727 & 0.07886 & 0.14966 & 0.09966 \\
\hline $\operatorname{nos} Z 1$ & A1_7862 & Bacteria & Proteobacteria & Alteromonadales & Alteromonadaceae & Gammaproteobacteria & Marinobacter & 0.01614 & 0.01127 & 0.00000 & 0.00747 \\
\hline $\operatorname{nos} Z 1$ & A1_788 & Bacteria & Proteobacteria & Rhodobacterales & Rhodobacteraceae & Alphaproteobacteria & Roseovarius & 0.08610 & 0.14270 & 0.19954 & 0.09468 \\
\hline $\operatorname{nos} Z 1$ & A1_827 & Bacteria & Proteobacteria & Pseudomonadales & Pseudomonadaceae & Gammaproteobacteria & Pseudomonas & 0.82333 & 0.87123 & 1.27706 & 1.16604 \\
\hline $\operatorname{nos} Z 1$ & C2_1511 & Bacteria & Proteobacteria & Rhizobiales & Bradyrhizobiaceae & Alphaproteobacteria & Bradyrhizobium & 0.00000 & 0.00000 & 0.00998 & 0.00000 \\
\hline $\operatorname{nosZ} 1$ & C2_4712 & Bacteria & Proteobacteria & Rhizobiales & Bradyrhizobiaceae & Alphaproteobacteria & Bradyrhizobium & 0.00000 & 0.00000 & 0.00998 & 0.00249 \\
\hline $\operatorname{nos} Z 1$ & C2_7831 & Bacteria & Proteobacteria & Rhodocyclales & Rhodocyclaceae & Betaproteobacteria & Thauera & 0.00269 & 0.00000 & 0.00000 & 0.00000 \\
\hline $\operatorname{nos} z 1$ & C2_975 & Bacteria & Proteobacteria & Burkholderiales & Comamonadaceae & Betaproteobacteria & Acidovorax & 0.08072 & 0.11641 & 0.44897 & 0.23670 \\
\hline $\operatorname{nos} Z 1$ & DA1_5583 & Bacteria & Proteobacteria & Rhodobacterales & Rhodobacteraceae & Alphaproteobacteria & Roseovarius & 0.02960 & 0.04506 & 0.02993 & 0.04485 \\
\hline $\operatorname{nos} Z 1$ & DA2_28640 & Bacteria & Proteobacteria & Pseudomonadales & Pseudomonadaceae & Gammaproteobacteria & Pseudomonas & 0.01345 & 0.02253 & 0.01995 & 0.05980 \\
\hline $\operatorname{nos} Z$ II & A1_116 & Bacteria & Bacteroidetes & Flavobacteriales & Flavobacteriaceae & Flavobacteriia & Maribacter & 0.15337 & 0.16523 & 0.14966 & 0.15447 \\
\hline $\operatorname{nos} Z$ II & A1_4166 & Bacteria & Bacteroidetes & Flavobacteriales & Flavobacteriaceae & Flavobacteriia & Maribacter & 0.04305 & 0.02629 & 0.01995 & 0.05980 \\
\hline
\end{tabular}

(v128; http://www.arb-silva.de). 
Table S2. Real-time PCR conditions and respective sequencing primers

\begin{tabular}{|c|c|c|c|c|c|c|c|c|c|c|}
\hline \multirow{3}{*}{ Gene } & \multirow{3}{*}{ Primer } & \multirow{3}{*}{ Sequence } & \multirow{3}{*}{$\begin{array}{l}\text { Fragment } \\
\text { size (bp) }\end{array}$} & \multirow{3}{*}{$\begin{array}{l}\text { Annealing } \\
\text { temp }\left({ }^{\circ} \mathrm{C}\right)\end{array}$} & \multicolumn{6}{|c|}{ Standard curves real-time PCR ${ }^{d}$} \\
\hline & & & & & \multicolumn{3}{|c|}{ qPCR } & \multicolumn{3}{|c|}{ RT-qPCR } \\
\hline & & & & & $\begin{array}{l}\text { Standard } \\
(\mathrm{ng} / \mu \mathrm{L})^{\mathrm{e}}\end{array}$ & $\begin{array}{l}\mathrm{R}^{2} / \\
\text { Efficiency(\%) }\end{array}$ & $\begin{array}{l}\mathrm{Tm} \\
\left({ }^{\circ} \mathrm{C}\right)\end{array}$ & $\begin{array}{l}\text { Standard } \\
(\mathrm{ng} / \mu \mathrm{L})^{\mathrm{f}}\end{array}$ & $\begin{array}{l}\mathrm{R}^{2} / \\
\text { Efficiency(\%) }\end{array}$ & $\begin{array}{l}\mathrm{Tm} \\
\left({ }^{\circ} \mathrm{C}\right)\end{array}$ \\
\hline nirk & nirKC2F/nirKC2R ${ }^{2}$ & $\begin{array}{l}\text { TGCACATCGCCAACGGNATGTWYGG/ } \\
\text { GGCGCGGAAGATGSHRTGRTCNAC }\end{array}$ & 457 & $56^{a}$ & $0.01-5$ & 0.994 / 95 & 80.8 & N/A & N/A & N/A \\
\hline nirs & nirSC1F/nirSC1R ${ }^{2}$ & $\begin{array}{l}\text { ATCGTCAACGTCAARGARACVGG/ } \\
\text { TTCGGGTGCGTCTTSABGAASAG }\end{array}$ & 425 & $56^{a}$ & $0.01-25$ & $0.942 / 110$ & 88.4 & $0.01-10$ & $0.937 / 103$ & 86.7 \\
\hline $\operatorname{nos} Z$ & $\operatorname{nosZF2} / \operatorname{nosZR2}{ }^{9}$ & $\begin{array}{l}\text { CGCRACGGCAASAAGGTSMSSGT/ } \\
\text { CAKRTGCAKSGCRTGGCAGAA }\end{array}$ & 267 & $60^{b}$ & $0.01-25$ & $0.980 / 106$ & 85.4 & $0.01-10$ & $0.950 / 94$ & 86.2 \\
\hline
\end{tabular}

${ }^{a}$ Thermal cycling conditions consisted of an initial denaturation step of 95 ㅇ for $10 \mathrm{~min}$, followed by 40 cycles of 95 ㅇ for $30 \mathrm{~s}$, annealing at 56 으 for $30 \mathrm{~s}$ and 72 으 for $30 \mathrm{~s}$,

with a final extension step of $10 \mathrm{~min}$ at 72 ㅇ. .

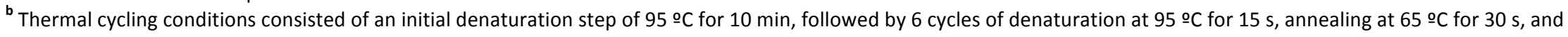

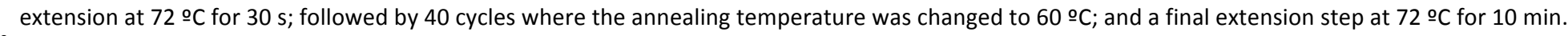

${ }^{c}$ Thermal cycling conditions consisted of an initial denaturation step of $95 \circ \mathrm{C}$ for $10 \mathrm{~min}$, followed by 8 cycles of denaturation at 94 으 for $30 \mathrm{~s}$, annealing at $65 \stackrel{\circ}{ } \mathrm{C}$ for $30 \mathrm{~s}$, and extension at 72 ㅇ C for $30 \mathrm{~s}$; followed by 27 cycles where the annealing temperature was changed to 57 우; and a final extension step at 72 ㅇ C for 10 min.

${ }^{d}$ Reaction mixture $(20 \mu \mathrm{l}): 10 \mu \mathrm{l}$ of Power SYBR Green PCR Master Mix (ThermoFisher Scientific), $0.6 \mu \mathrm{M}$ of primers and $1 \mu \mathrm{l}$ of template.

e Standards consisted on linearized plasmid DNA obtained after cloning conventional PCR products for each gene. Standard curves were made with 5 serial dilutions and the ranges are presented for each gene.

${ }^{f}$ Standards consisted on cDNA pooled from eight microcosms samples. Standard curves were made with 5 serial dilutions and the ranges are presented for each gene. N/A - not applicable. 
Table S3. $p$-values of the regressions over time for microcosms exposed to Cu NPs $<50 \mathrm{~nm}$ (EXP50) and exposed to Cu NPs $<150 \mathrm{~nm}$ (EXP150), and $p$-values for the $t$-test comparing the slopes of both EXP

\begin{tabular}{lll} 
& $\mathrm{pH}$ & $\mathrm{N}-\mathrm{NO}_{3}{ }^{-}$water \\
\hline EXP50 & $1.68 \mathrm{E}-04$ & $9.59 \mathrm{E}-07$ \\
EXP150 & $1.04 \mathrm{E}-03$ & $1.63 \mathrm{E}-02$ \\
& & \\
EXP50 vs EXP150 & $6.86 \mathrm{E}-01$ & $7.40 \mathrm{E}-05$ \\
\hline
\end{tabular}




\section{Supplementary Figures}

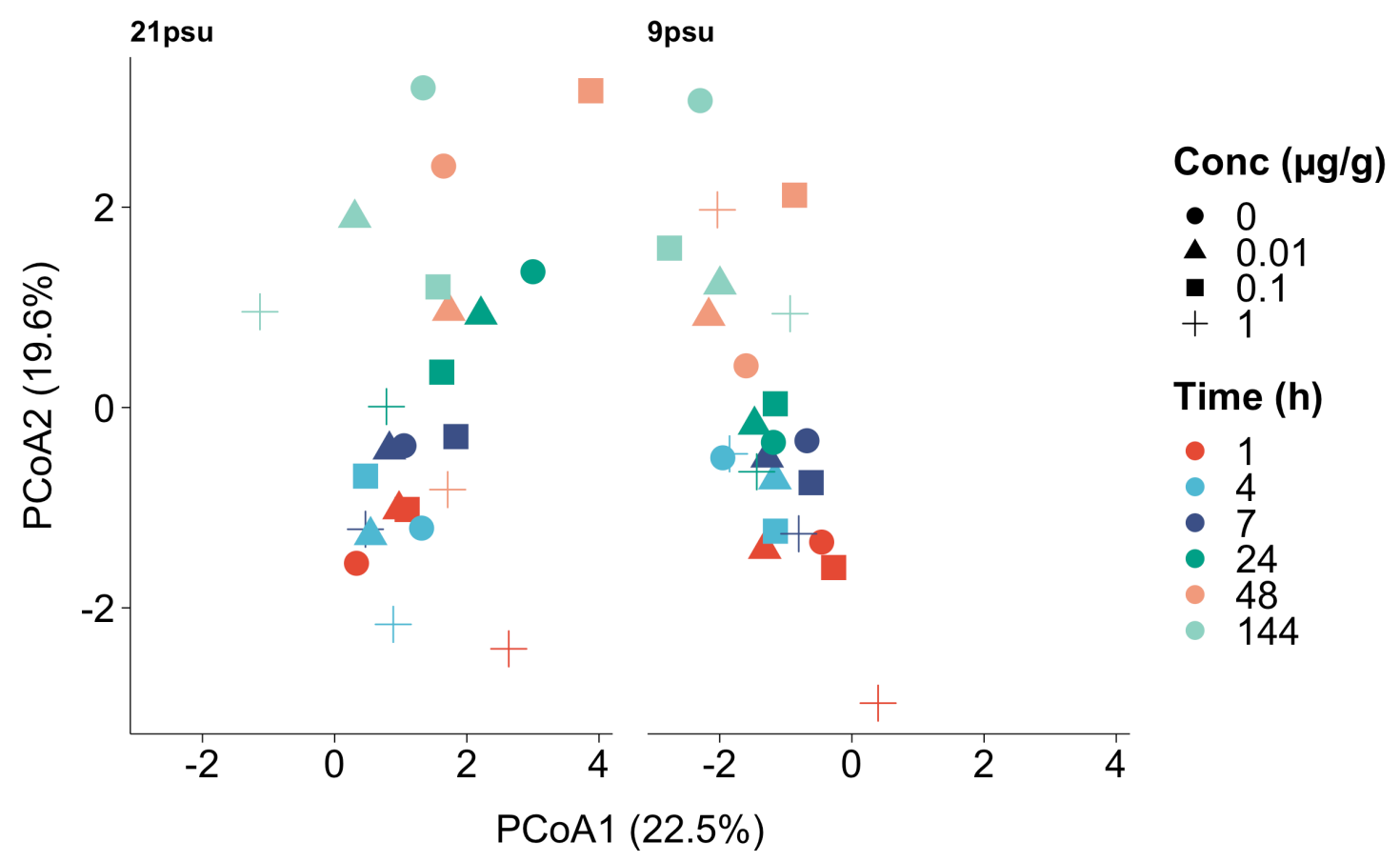

Fig. 1S Microcosms response throughout the exposure period under different salinities (9

psu and 21 psu). Principal component analysis showing the $\mathrm{Cu}$ concentration throughout time to behave similarly in microcosms exposed to Cu NPs $<50 \mathrm{~nm}$ under different salinity regimes. 

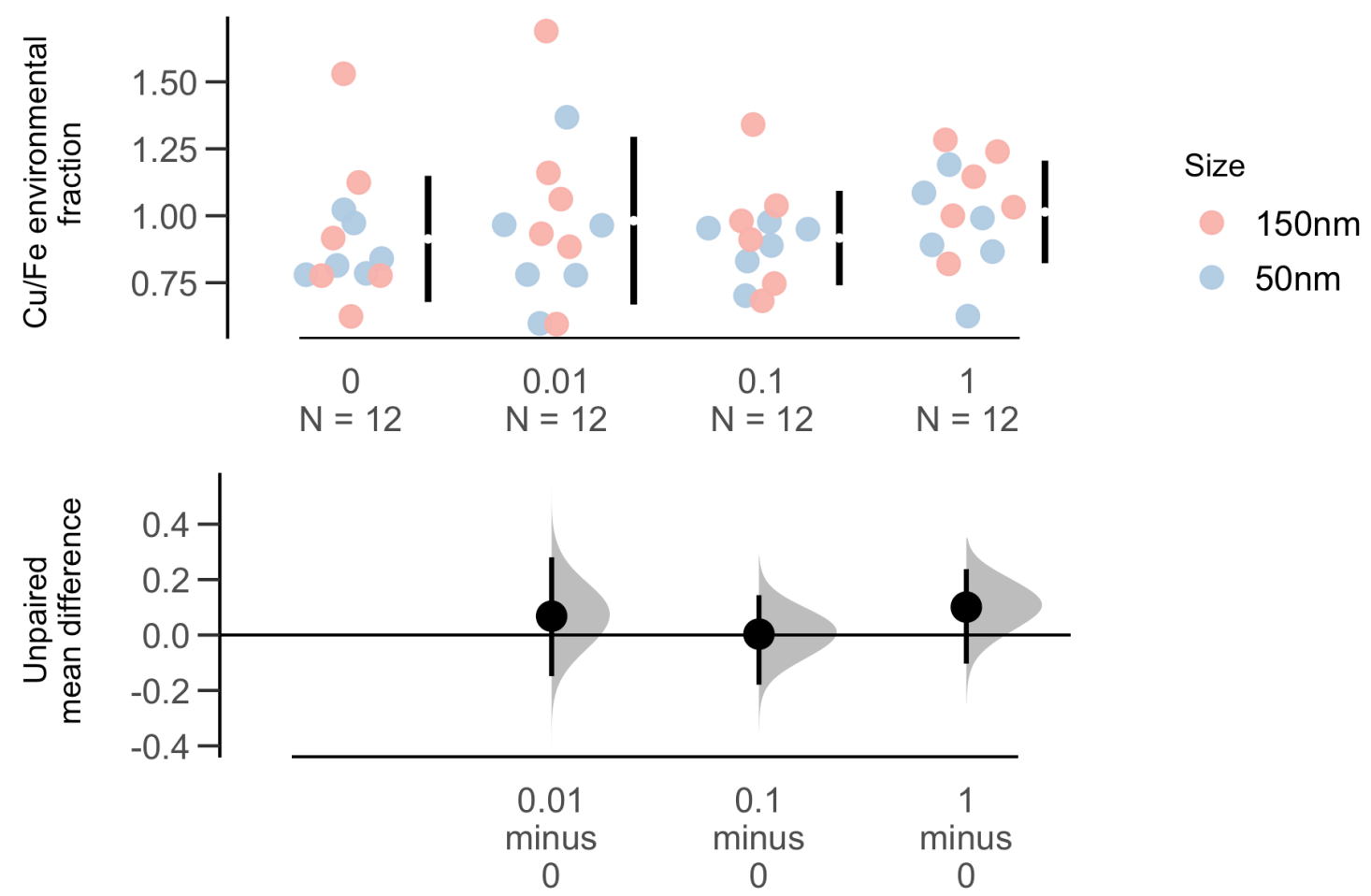

Fig. 2S Estimation plot of Cu environmental fraction normalised to Fe. Results are reported for microcosms exposed to Cu NPs 0, 0.01, 0.1 and $1 \mu \mathrm{g} \mathrm{g}{ }^{-1}$. Gapped lines to the right of each concentration group are mean value \pm standard deviation and the effect size, with $95 \%$ confidence intervals, is plotted below. 


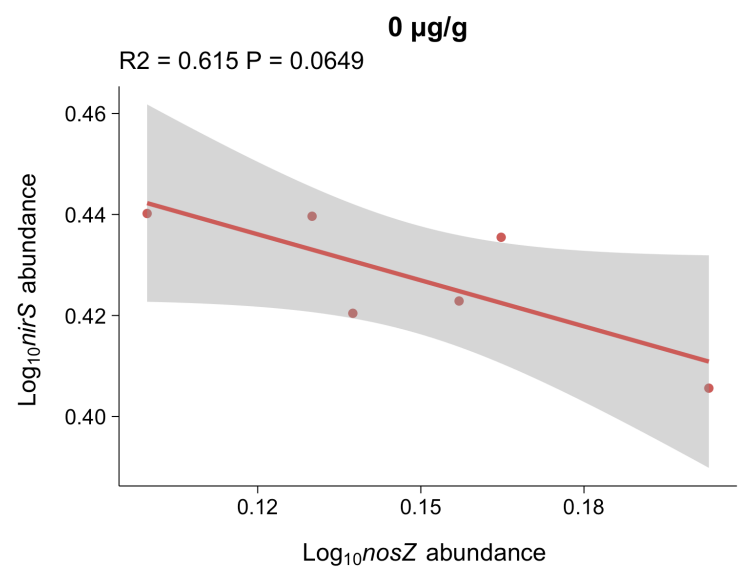

$0.1 \mu \mathrm{g} / \mathrm{g}$

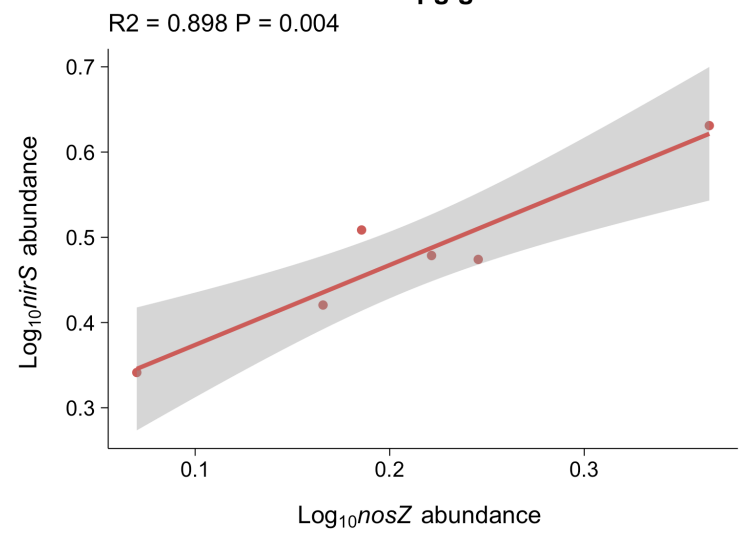

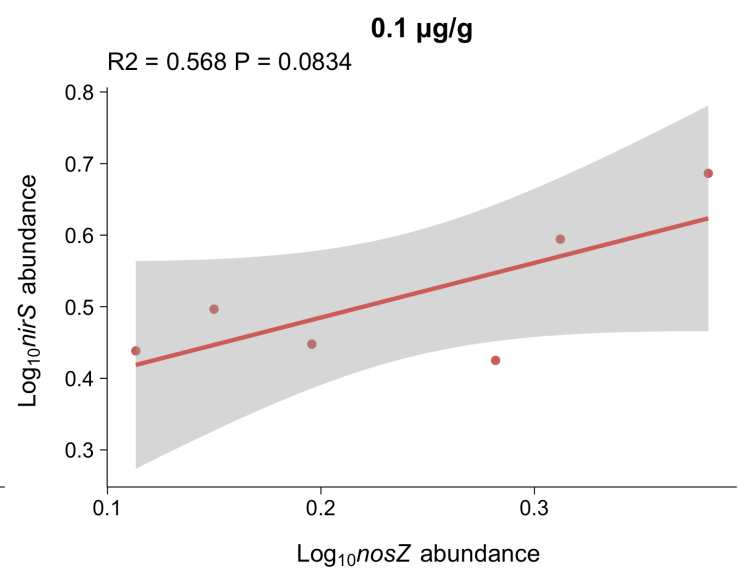

$1 \mu \mathrm{g} / \mathrm{g}$

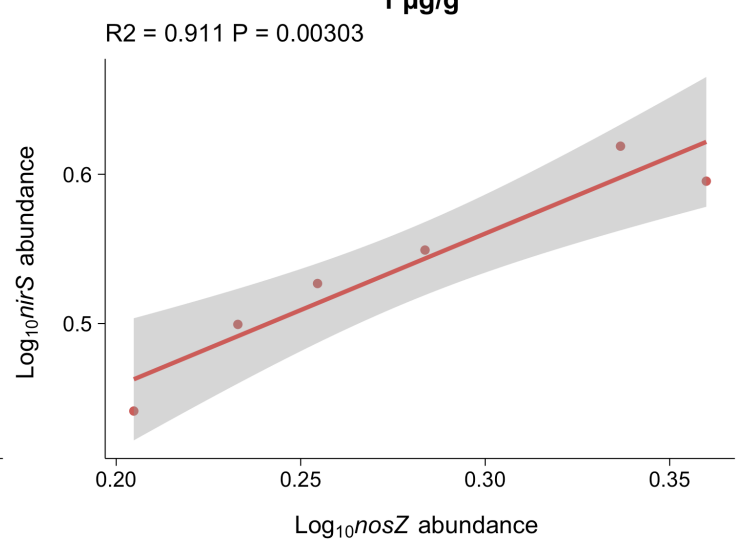

Fig. 35 Correlation between nirS and nosZ abundances in microcosms exposed to Cu NPs $<$

$50 \mathbf{~ n m}$. A) microcosms not exposed to Cu NPs; B) microcosms exposed to $0.01 \mu \mathrm{g} \mathrm{g}^{-1}$; C)

microcosms exposed to $0.1 \mu \mathrm{g} \mathrm{g}^{-1}$; and D) microcosms exposed to $1 \mu \mathrm{g} \mathrm{g} \mathrm{g}^{-1}$. Gene copy number per gram dry sediment were $\log 10$ transformed and nirS and nos $Z$ values were normalized by the $16 S$ rRNA gene. Points are the average of two replicates, with a RSD between 9 and $24 \%$ and the linear regression is shown with $95 \%$ confidence interval. 


\section{References}

1 C. M. Jones, B. Stres, M. Rosenquist and S. Hallin, Phylogenetic Analysis of Nitrite, Nitric Oxide, and Nitrous Oxide Respiratory Enzymes Reveal a Complex Evolutionary History for Denitrification, Mol. Biol. Evol., 2008, 25, 1955-1966.

2 W. Wei, K. Isobe, T. Nishizawa, L. Zhu, Y. Shiratori, N. Ohte, K. Koba, S. Otsuka and K. Senoo, Higher diversity and abundance of denitrifying microorganisms in environments than considered previously, ISME J., 2015, 9, 1954-1965.

3 D. Helen, H. Kim, B. Tytgat and W. Anne, Highly diverse nirk genes comprise two major clades that harbour ammonium-producing denitrifiers, BMC Genomics, 2016, 17, 155.

4 C. M. Jones, D. R. Graf, D. Bru, L. Philippot and S. Hallin, The unaccounted yet abundant nitrous oxide-reducing microbial community: a potential nitrous oxide sink, ISME J., 2013, 7, 417-426.

5 S. Hallin and P.-E. Lindgren, PCR Detection of Genes Encoding Nitrite Reductase in Denitrifying Bacteria, Appl. Environ. Microbiol., 1999, 65, 1652-1657.

6 G. Braker, A. Fesefeldt and K.-P. Witzel, Development of PCR Primer Systems for Amplification of Nitrite Reductase Genes (nirk and nirS) To Detect Denitrifying Bacteria in Environmental Samples, Appl. Environ. Microbiol., 1998, 64, 3769-3775.

7 V. Michotey, V. Méjean and P. Bonin, Comparison of Methods for Quantification of Cytochrome cd1-Denitrifying Bacteria in Environmental Marine Samples, Appl. Environ. Microbiol., 2000, 66, 1564-1571.

8 I. N. Throbäck, K. Enwall, Å. Jarvis and S. Hallin, Reassessing PCR primers targeting nirS, nirK and nosZ genes for community surveys of denitrifying bacteria with DGGE, FEMS Microbiol. Ecol., 2004, 49, 401-417.

9 S. Henry, D. Bru, B. Stres, S. Hallet and L. Philippot, Quantitative Detection of the nosZ Gene, Encoding Nitrous Oxide Reductase, and Comparison of the Abundances of $16 \mathrm{~S}$ rRNA, narG, nirk, and nosZ Genes in Soils, Appl. Environ. Microbiol., 2006, 72, 5181-5189.

10 C. M. Jones, A. Spor, F. P. Brennan, M.-C. Breuil, D. Bru, P. Lemanceau, B. Griffiths, S. Hallin and L. Philippot, Recently identified microbial guild mediates soil N2O sink capacity, Nat. Clim. Change, 2014, 4, 801-805.

11 J. P. Santos, D. Mendes, M. Monteiro, H. Ribeiro, M. S. Baptista, M. T. Borges and C. Magalhães, Salinity impact on ammonia oxidizers activity and amoA expression in estuarine sediments, Estuar. Coast. Shelf Sci., 2018, 211, 177-187.

12 D. R. H. Graf, C. M. Jones and S. Hallin, Intergenomic Comparisons Highlight Modularity of the Denitrification Pathway and Underpin the Importance of Community Structure for N2O Emissions, PLOS ONE, 2014, 9, e114118.

$13 \mathrm{~J}$. A. Lee and C. A. Francis, Spatiotemporal Characterization of San Francisco Bay Denitrifying Communities: a Comparison of nirK and nirS Diversity and Abundance, Microb. Ecol., 2017, 73, 271-284.

14 R. Bartossek, G. W. Nicol, A. Lanzen, H.-P. Klenk and C. Schleper, Homologues of nitrite reductases in ammonia-oxidizing archaea: diversity and genomic context: Nitrite reductase of soil archaea, Environ. Microbiol., 2010, 12, 1075-1088.

15 C. E. Dandie, S. Wertz, C. L. Leclair, C. Goyer, D. L. Burton, C. L. Patten, B. J. Zebarth and J. T. Trevors, Abundance, diversity and functional gene expression of denitrifier communities in adjacent riparian and agricultural zones: Denitrifiers in riparian and agricultural soils, FEMS Microbiol. Ecol., 2011, 77, 69-82.

16 X. Huang, CAP3: A DNA Sequence Assembly Program, Genome Res., 1999, 9, 868-877.

$17 \mathrm{~K}$. Okonechnikov, O. Golosova and M. Fursov, Unipro UGENE: a unified bioinformatics toolkit, Bioinformatics, 2012, 28, 1166-1167.

18 S. F. Altschul, W. Gish, W. Miller, E. W. Myers and D. J. Lipman, Basic local alignment search tool, J. Mol. Biol., 1990, 215, 403-410. 
19 C. M. Magalhães, A. Machado, B. Frank-Fahle, C. K. Lee and S. C. Cary, The ecological dichotomy of ammonia-oxidizing archaea and bacteria in the hyper-arid soils of the Antarctic Dry Valleys, Front. Microbiol., , DOI:10.3389/fmicb.2014.00515.

20 F. Bonk, D. Popp, H. Harms and F. Centler, PCR-based quantification of taxa-specific abundances in microbial communities: Quantifying and avoiding common pitfalls, $J$. Microbiol. Methods, 2018, 153, 139-147.

21 S. F. Stoddard, B. J. Smith, R. Hein, B. R. K. Roller and T. M. Schmidt, rrnDB: improved tools for interpreting rRNA gene abundance in bacteria and archaea and a new foundation for future development, Nucleic Acids Res., 2015, 43, D593-D598.

22 G. Muyzer, E. C. de Waal and A. G. Uitterlinden, Profiling of complex microbial populations by denaturing gradient gel electrophoresis analysis of polymerase chain reaction-amplified genes coding for $16 \mathrm{~S}$ rRNA, Appl. Environ. Microbiol., 1993, 59, 695-700. 